\title{
Occurrence and significance of atypical Aeromonas salmonicida in non-salmonid and salmonid fish species: a review
}

\author{
Tom Wiklund ${ }^{1, *}$, Inger Dalsgaard ${ }^{2}$ \\ ${ }^{1}$ Institute of Parasitology and Department of Biology, Åbo Akademi University, BioCity, Artillerigatan 6, SF-20520 Åbo, Finland \\ ${ }^{2}$ Danish Institute for Fisheries Research, Fish Disease Laboratory, Bülowsvej 13, DK-1870 Frederiksberg C, Denmark
}

\begin{abstract}
Bacterial strains of Aeromonas salmonicida included in the recognized subsp. achromogenes, subsp. masoucida, and subsp. smithia in addition to the large number of strains not included in any of the described subspecies are referred to as atypical A. salmonicida. The atypical strains form a very heterogeneous group with respect to biochemical characteristics, growth conditions, and production of extracellular proteases. Consequently, the present taxonomy of the species $A$. salmonicida is rather ambiguous. Atypical A. salmonicida has been isolated from a wide range of cultivated and wild fish species, non-salmonids as well as salmonids, inhabitıng fresh water, brackish water and marine environments in northern and central Europe, South Africa, North America, Japan and Australia. In non-salmonid fish species, infections with atypical strains often manifest themselves as superficial skin ulcerations. The best known diseases associated with atypical A. salmonicida are carp Cyprinus carpio erythrodermatitis, goldfish Carassius auratus ulcer disease, and ulcer disease of flounder Platichthys flesus, but atypical strains are apparently involved in more disease outbreaks than previously suspected. Macroscopical and microscopical studies of ulcerated fish indicate internal organs are infrequently invaded by atypical $A$. salmonicida. This view is supported by the fact that atypical strains are irregularly isolated from visceral organs of ulcerated fish. High mortality caused by atypical $A$. salmonicida has been observed in populations of wild non-salmonids and farmed salmonids, although the association between the mortality in the wild fish stocks and atypical $A$. salmonicida has not always been properly assessed. In injection experiments the pathogenicity of the atypical strains examined showed large variation. An extracellular A-layer has been detected in different atypical strains, but virulence mechanisms different from those described for (typical) A. salmonicida subsp. salmonicida, for example an extracellular metallo-protease and a different iron utilization mechanism, have been described. Limited information is available about the ecology, spread and survival of atypical strains in water. The commonly used therapeutic methods for the control of diseases in farmed fish caused by atypical $A$. salmonicida are generally effective against the atypical strains. Resistance to different antibiotics and transferable plasmids encoding multiple drug resistance have been observed in atypical A. salmonicida. Studies aimed at producing a vaccine against atypical strains are in progress.
\end{abstract}

KEY WORDS: Aeromonas salmonicida - Skin ulcers · Fish pathogens · Fish

\section{INTRODUCTION}

The expression 'atypical Aeromonas salmonicida' was initially used for bacterial strains belonging to the spe-

\footnotetext{
- Present address: Danish Institute for Fisheries Research, Fish Disease Laboratory, Bülowsvej 13, DK-1870 Frederiksberg C, Denmark. E-mail: tow@kvl.dk
}

cies $A$. salmonicida but showing biochemical characteristics, mainly slow growth and late pigment production, different from those described for A. salmonicida subsp. salmonicida. One of the first papers using the expression 'atypical' or 'aberrant' strain of A. salmonicida was published in 1971 (Evelyn 1971), although reports on strains not included in subsp. salmonicida had been published earlier (Smith 1963, Kimura 1969a, b). 
Although several subspecies of Aeromonas salmonicida have been described, i.e. subsp. achromogenes, subsp. masoucida, subsp. salmonicida and subsp. smithia (Holt et al. 1994), a large number of reported strains have not been assigned to any of these subspecies. Presently, strains included in the subsp. achromogenes, subsp. masoucida, and subsp. smithia in addition to the strains not included in any of the described subspecies of $A$. salmonicida are referred to as atypical strains. Strains of subsp. salmonicida are consequently referred to as 'typical' A. salmonicida. Although strains showing characteristics that are different from those described for typical $A$. salmonicida are considered to be atypical isolates, several papers on typical strains have recently been published showing atypical or aberrant biochemical characteristics, such as non- or late-pigmentation (Wiklund et al. 1993), negative cytochrome oxidase reaction (Chapman et al. 1991), acid production from sucrose (Wiklund et al. 1992), no degradation of aesculin (Austin et al. 1989), production of hydrogen sulfide (Austin et al. 1989) and growth at $37^{\circ} \mathrm{C}$ (McIntosh \& Austin 1991).

The number of published reports of disease outbreaks associated with atypical strains has increased significantly during the last decade, and these isolates have been reported from an increasing number of fish species and geographical areas. Most of the isolated strains have been identified as atypical Aeromonas salmonicida and very few of them are included in any of the described subspecies (subsp. achromogenes, subsp. masoucida, and subsp. smithia) (Holt et al. 1994). In fact, new isolates of $A$. salmonicida subsp. masoucida and subsp. smithia have not been reported since their initial isolation and description (Kimura 1969a, b, Austin et al. 1989).

Diseases caused by atypical strains have been referred to as ulcer disease or 'atypical furunculosis' (Snieszko et al. 1950, Hubbert \& Williams 1980, Groman et al. 1992, Wiklund 1994b, Gudmundsdóttir \& Magnadóttir 1997) in contrast to furunculosis or classical furunculosis caused by typical Aeromonas salmonicida. Unfortunately, clinical infections in fish with atypical $A$. salmonicida have sometimes in the literature been referred to as furunculosis (McCarthy 1975 , Bucke 1980, Boomker et al. 1984), which in the opinion of the present authors should be avoided.

Atypical bacterial strains of the species Aeromonas salmonicida have been poorly defined, and this group consists of isolates showing a large variety of biochemical, molecular and virulence characteristics. Presently, an atypical strain can be defined only as a strain that does not fit into the existing classification of A. salmonicida subsp salmonicida. This situation certainly needs to be adequately solved in future detailed taxonomic studies.
This paper presents the current state of knowledge about the biology and the taxonomy of atypical Aeromonas salmonicida strains and disease processes generated by these bacteria.

\section{TAXONOMY}

The taxonomic position of Aeromonas salmonicida has been reviewed by McCarthy \& Roberts (1980) and Austin \& Austin (1993). In Bergey's Manual of Systematic Bacteriology (Popoff 1984), the genus Aeromonas was included in the family Vibrionaceae. The proposal to place this genus in the new family Aeromonadaceae (Colwell et al. 1986), which was based on molecular genetic data, has recently been validated (Anonymous 1992). The recognized species in the genus Aeromonas represent 14 clearly different DNA homology groups (Esteve et al. 1995) with A. salmonicida subsp. salmonicida belonging to DNA group 3.

According to the latest edition of Bergey's Manual of Systematic Bacteriology (Popoff 1984), Aeromonas salmonicida is divided into 3 subspecies: $A$. salmonicida subsp. salmonicida (Griffin et al. 1953a), A. salmonicida subsp. achromogenes (Smith 1963) and $A$. salmonicida subsp. masoucida (Kimura 1969a, b). This differentiation was proposed by Schubert $(1967,1969)$. These 3 subspecies can be distinguished by a limited number of biochemical characteristics (Popoff 1984).

Since the first description by Smith (1963) of strains different from Aeromonas salmonicida subsp. salmonicida, a large number of atypical strains of $A$. salmonicida have been isolated (e.g. Wiklund 1990, Austin \& Austin 1993, Nakatsugawa 1994, Wiklund \& Dalsgaard 1995). McCarthy \& Roberts (1980) have proposed another and different division into 3 subspecies, based on epizootiological criteria. The 3 subspecies are subsp. salmonicida, subsp. achromogenes (incorporating subsp. masoucida, including only strains isolated from salmonids), and subsp, nova (isolated from non-salmonid fish). This classification has not been approved in Bergey's Manual of Systematic Bacteriology (Popoff 1984). A. salmonicida subsp. salmonicida and $A$. salmonicida subsp. masoucida were found to be a genetically homogenous group in DNA homology studies (MacInnes et al. 1979). Based on numerical taxonomy (McCarthy 1978), sequence homology, and guanine-plus-cytosine content $(\% \mathrm{G}+\mathrm{C})$ (Belland \& Trust 1988), the subspecies achromogenes should be restructured to include the present subspecies masoucida. The close genetic relatedness of these subspecies was also shown by Martinez-Murcia et al. (1992), in contrast to the findings of Austin et al. (1989) which supported the separation of the 2 subspecies. However, in Bergey's Manual of Determinative Bac- 
teriology (Holt et al. 1994) the 3 subspecies from the approved list (Skerman et al. 1980) are included together with a new subgroup, subsp. smithia, which was created by Austin et al. (1989).

In the description of Aeromonadaceae (Colwell et al. 1986) the $\% \mathrm{G}+\mathrm{C}$ content of the DNA ranged from 40 to $63 \mathrm{~mol} \%$. The $\% \mathrm{G}+\mathrm{C}$ contents of the DNA of subspecies of Aeromonas salmonicida in different studies ranged from 52 to $67 \mathrm{~mol} \%$ (Table 1). The $\% \mathrm{G}+\mathrm{C}$ values given in Table 1 do not allow for distinction of the different subspecies.

Although several studies have described the genetic relationships between the species within the genus Aeromonas, there is still a lack of reliable traits for subspecies discrimination, especially for the slow-growing fastidious strains which have been isolated during the past few years (Pedersen et al. 1994, Wiklund et al. 1994). Further studies have to be based on large numbers of strains and use more modern techniques such as poly-nucleotide sequencing and DNA-DNA or RNA-DNA hybridization.

\section{IDENTIFICATION AND CHARACTERIZATION}

The genus Aeromonas (Kluyver \& Van Niel 1936) consists of a collection of oxidase- and catalase-positive glucose-fermenting, facultatively anaerobic, Gramnegative, rod-shaped bacteria (Popoff 1984) that are resistant to vibriostatic agent $\mathrm{O} / 129(10 \mu \mathrm{g})$ and novo-

Table 1. Aeromonas salmonicida subspecies. Base composition of the DNA. G+C: guanine-plus-cytosine, nd: no data available

\begin{tabular}{|lcl|}
\hline $\begin{array}{l}\text { Subspecies } \\
\text { or group }\end{array}$ & $\begin{array}{c}\text { G+C contents } \\
\text { mol\% }\end{array}$ & \multicolumn{1}{c|}{ Source } \\
\hline A. salmonicida & $55.1-57.5$ & McCarthy (1978) \\
& 52.7 & $\begin{array}{l}\text { Maclnnes et al. (1979) } \\
\text { Popoff (1984) }\end{array}$ \\
& $52.6-57.8$ & Belland \& Trust (1988) \\
A. achromogenes & 52.9 & McCarthy (1975) \\
& 59.7 & Belland \& Trust (1988) \\
A. masoucida & 60.0 & Belland \& Trust (1988) \\
A. nova & $56.1-57.6$ & McCarthy (1978) \\
A. smithia & $55.9 \pm 0.5$ & Austin et al. (1989) \\
Phenon 13 & nd & Austin et al. (1989) \\
Slow-growing & $54.0-66.9$ & Wiklund et al. (1994) \\
fastidious (flatfish) & & Bootsma et al. (1977) \\
Atypical strains & $56.5-58.6$ & McCarthy (1978) \\
& $55.4-57.1$ & Paterson et al. (1980b) \\
& 57.9 & Shotts et al. (1980) \\
& 57.0 & Trust et al. (1980b) \\
& $54.4-56.1$ & Kitao et al. (1984) \\
& 57.3 & Ohtsuka et al. (1984) \\
& $59.0-59.3$ & Belland \& Trust (1988) \\
& $52.4-57.8$ & \\
\hline
\end{tabular}

biocin (5 $\mu \mathrm{g}$ ) (Magariños et al. 1992). With respect to motility, the genus consists of 2 well-separated groups with the species and subspecies of Aeromonas salmonicida belonging to the non-motile group. The optimal growth temperature for $A$. salmonicida is 20 to $22^{\circ} \mathrm{C}$ (Paterson et al. 1980a). Growth may be accompanied by the release of a brown pigment which is a property used in the classification of $A$. salmonicida subspecies (Griffin et al. 1953b, Donlon et al. 1983, Altmann et al. 1992). The existence of achromogenic or slowly pigmenting strains of $A$. salmonicida has been described, with the consequence that different strains have not been properly identified (Bulkley 1969, Mawdesley-Thomas 1969, LeTendre et al. 1972, Michel $1981)$.

According to Schubert (1967), Aeromonas salmonicida subsp. achromogenes differs only in a few properties from subsp. salmonicida. Identification of atypical A. salmonicida strains to the genus level is easily achieved with sufficient experience. However, reports published on the isolation of cytochrome oxidase negative atypical as well as typical strains (Traxler \& Bell 1988, Chapman et al. 1991, Olivier 1992, Pedersen et al. 1994, Wiklund et al. 1994) have complicated identification. In addition, the fermentative reaction of glucose in Hugh \& Leifson's medium sometimes requires prolonged incubation, especially for the identification of the slow-growing fastidious strains isolated from flatfish (Pedersen et al. 1994, Wiklund et al. 1994).

Identification to the species level can be further confirmed by demonstrating the antigenic similarity between the typical and atypical strains with respect to the thermostable O-antigen, by macroscopic slide agglutination using antiserum prepared from an isolate of Aeromonas salmonicida subsp. salmonicida (McCarthy 1977, Trust et al. 1980c, Pedersen et al. 1994) or a hybridoma producing a highly specific monoclonal antibody against $A$. salmonicida (Yoshimizu et al. 1993).

Biochemical characteristics useful for distinguishing the different atypical subspecies of Aeromonas salmonicida from the homogenous and well-described $A$. salmonicida subsp. salmonicida are summarized in Table 2. The identification of atypical strains and the separation of these from subsp. salmonicida has been complicated because strains of subsp. salmonicida have been found to differ in the key characteristics: pigment production (Wiklund et al. 1993), cytochrome oxidase activity (Chapman et al. 1991), and acid from sucrose (Wiklund et al. 1992). An accurate biochemical identification of atypical A. salmonicida based on a comparison of inter-laboratory evaluations has proven difficult; likewise data presented in the literature on various strains of $A$. salmonicida are not readily comparable (Dalsgaard et al. 1998). 
Table 2. Aeromonas salmonicida. Characteristics for differentiation between subspecies and atypical isolates. + : positive reaction; -: negative reaction; ( ): reaction of a few strains; S: sensitive; R: resistant; nd: no data available

\begin{tabular}{|c|c|c|c|c|c|c|c|c|}
\hline $\begin{array}{l}\text { Subspecies } \\
\text { or group }\end{array}$ & $\begin{array}{l}\text { Pigment } \\
\text { production }\end{array}$ & $\begin{array}{l}\text { Oxidase } \\
\text { reaction }\end{array}$ & $\begin{array}{l}\text { Gas from } \\
\text { glucose }\end{array}$ & $\begin{array}{l}\text { Acid from } \\
\text { sucrose }\end{array}$ & $\begin{array}{l}\text { Indole } \\
\text { production }\end{array}$ & $\begin{array}{l}\text { Degradation } \\
\text { of aesculin }\end{array}$ & $\begin{array}{l}\text { Sensitivity } \\
\text { to ampicillin }\end{array}$ & $\begin{array}{l}\text { Sensitivity to } \\
\text { cephalothin }\end{array}$ \\
\hline A. salmonicidad & $+(-)$ & $+(-)$ & + & $-(+)$ & - & + & $\mathrm{S}$ & $\mathrm{s}$ \\
\hline A. achromogenes & $-1+1$ & + & - & + & + & - & $\mathrm{R}$ & $\mathrm{R}$ \\
\hline A. masoucida ${ }^{a}$ & - & + & + & + & + & + & nd & nd \\
\hline A. nova & $-1+$ & + & - & $+1-$ & $+(-)$ & $-1+$ & $\mathrm{R} / \mathrm{S}$ & $\mathrm{R} / \mathrm{S}$ \\
\hline A. smithia ${ }^{c}$ & $-(+)$ & + & nd & $+(-)$ & - & - & $S(R)$ & nd \\
\hline Phenon $13^{c}$ & $+(-)$ & + & nd & + & - & - & $\mathrm{R}$ & nd \\
\hline Slow-growing ${ }^{d}$ & - & $-1+$ & - & $+/-$ & $-(+)$ & $+(-)$ & $\mathrm{S}$ & $S(R)$ \\
\hline Atypical isolates ${ }^{e}$ & $+1-$ & + & - & + & $-1+$ & $-(+)$ & $R(S)$ & $\mathrm{R}(\mathrm{S})$ \\
\hline \multirow{2}{*}{\multicolumn{9}{|c|}{ "Popoff (1984), Chapman et al. (1991), Wiklund et al. $(1992,1993)$}} \\
\hline \multirow{2}{*}{\multicolumn{9}{|c|}{$\begin{array}{l}\text { bcCarthy (1978), Böhm et al. (1986), Olivier (1992) } \\
\text { cAustin et al. (1989) }\end{array}$}} \\
\hline & & & & & & & & \\
\hline \\
\hline \multicolumn{9}{|c|}{ 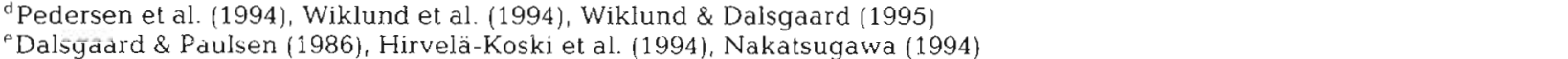 } \\
\hline
\end{tabular}

McCarthy (1978), Böhm et al. (1986) and Olivier (1992) classified the examined atypical strains as subspecies achromogenes and nova. Some important characteristics of these isolates were the same for all strains (Table 2), but subspecies nova seemed to be more fastidious and growth could require up to $5 \mathrm{~d}$ incubation at $22^{\circ} \mathrm{C}$.

Austin et al. (1989) used numerical taxonomy and DNA:DNA hybridization techniques to group Aeromonas salmonicida into 5 phena, which were equated with the subspecies salmonicida, masoucida, achromogenes and smithia and a fifth group (phenon 13) comprising unrecognized subspecies. Further strains which were able to grow at $37^{\circ} \mathrm{C}$ were included in the fifth group (Austin 1993).

The plasmid profiles reported from atypical strains of Aeromonas salmonicida were different from the plasmids carried by typical strains (Bast et al. 1988, Belland \& Trust 1989, Pedersen et al. 1996), and Belland \& Trust (1989) suggested that plasmid content may be a useful epizootiological marker for atypical $A$. salmonicida. The results presented by Pedersen et al. (1996) indicated that plasmid profiles of atypical strains may change considerably in vivo and several epizootiologically related strains showed different profiles. Similarly, the variability observed in plasmids in different strains isolated from flounder Platichthys flesus seemed to be of no value for epizootiological work because variability occurred within the isolates from the same geographical area (Dalsgaard 1994a). In contrast to plasmid profiles, ribotypes never showed variation upon repeated testing (Pedersen et al. 1996). Most epizootiologically unrelated strains had different ribotypes, whereas isolates from the same outbreak were identical. The data obtained so far suggest that ribotyping can permit the identification of subgroups, which may be useful in epizootiological studies (McCormick et al. 1990, Dalsgaard 1994a, Whittington et al. 1995, Pedersen at al. 1996).

\section{HOST RANGE}

Atypical Aeromonas salmonicida strains have been isolated from a wide range of fish species belonging to different families and orders (Table 3). More than 20 farmed and 30 wild fish species have been reported to harbor atypical $A$. salmonicida strains. Initially, atypical A. salmonicida strains were predominantly recovered from fresh water or anadromous fish species. However, more recently atypical strains have repeatedly been isolated from marine fish species, like flatfish (order Pleuronectiformes) and codfish (order Gadiformes), as well as catadromous fish species, like eels (family Anguillidae) (Table 3).

\section{Non-salmonids}

With regard to non-salmonid wild fish, atypical Aeromonas salmonicida has been isolated from occasional cases of ulcerated or otherwise diseased fish from nature or from wild fish kept in aquaria or tanks (Evelyn 1971, Cornick et al. 1984, Dalsgaard \& Paulsen 1986, Wiklund 1990, Wilson \& Holliman 1994). In a few cases, atypical $A$. salmonicida has been associated with epizootics in wild fish populations (Bulkley 1969, McCarthy 1975, Håstein et al. 1978, Michel 1981).

In several studies atypical Aeromonas salmonicida has been isolated from fish which after capture were transferred to tanks, aquaria or net pens. This was the case, for example, for sablefish Anoplopoma fimbria (Evelyn 1971), Atlantic cod Gadus morhua (Cornick et al. 1984) and Pacific herring Clupea harengus pallasi in Canada (Traxler \& Bell 1988), sand-eels Hyperoplus lanceolatus and Ammodytes lancea in Denmark (Dalsgaard \& Paulsen 1986), and greenback flounder Rhombosolea tapirina in Tasmania (Whittington et al. 1995). 
Table 3. Aeromonas salmonicida. Isolates of atypical A. salmonicida from farmed and wild fish species in different countries

\begin{tabular}{|c|c|c|c|}
\hline Fish species & Scientific name & Country & Source \\
\hline \multicolumn{4}{|l|}{ Order Anguilliformes } \\
\hline \multicolumn{4}{|l|}{ FARMED FISH } \\
\hline American eel & Anguilla rostrata & USA & Noga \& Berkhoff (1990) \\
\hline European eel & Anguilla anguilla & Denmark" & Dalsgaard (1994b) \\
\hline Japanese eel & Anguilla japonica & Japan & Ohtsuka et al. (1984) \\
\hline \multicolumn{4}{|l|}{ WILD FISH } \\
\hline American eel & Anguilla rostrata & Canada. USA & Olivier (1992), Noga \& Berkhoff (1990) \\
\hline European eel & Anguilla anguilla & Denmark & Dalsgaard (1994b) \\
\hline \multicolumn{4}{|l|}{ Order Clupeiformes } \\
\hline Pacific herring & Clupea harengus pallasi & Canada ${ }^{d}$ & Traxler \& Bell (1988) \\
\hline \multicolumn{4}{|l|}{$\begin{array}{l}\text { Order Cypriniformes } \\
\text { FARMED FISH }\end{array}$} \\
\hline \multirow{6}{*}{ Carp } & Cyprinus carpio & Australia & Humphrey \& Ashburner (1993) \\
\hline & & Denmark ${ }^{b}$ & Belland \& Trust (1988) \\
\hline & & Germany & Böhm et al. (1986), Mirle et al. (1986) \\
\hline & & Hungary & Csaba et al. (1980a) \\
\hline & & $\begin{array}{l}\text { Netherlands }{ }^{b} \\
\text { UK }^{\mathrm{b}}\end{array}$ & $\begin{array}{l}\text { Ishiguro et al. }(1986) \\
\text { Austin }(1993)\end{array}$ \\
\hline & & Yugoslavia & Bootsma et al. (1977) \\
\hline \multirow[t]{9}{*}{ Goldfish } & Carassius auratus & Australia & Trust et al. (1980c), Humphrey \& Ashburner (1993) \\
\hline & & Denmark & Dalsgaard (unpubl. data) \\
\hline & & Germany & Böhm et al. (1986) \\
\hline & & Italy ${ }^{\mathrm{b}}$ & Whittington et al. (1987) \\
\hline & & Japan & Elliott \& Shotts (1980a) \\
\hline & & Netherlands ${ }^{b}$ & Evenberg et al. (1982) \\
\hline & & Singapore & Whittington et al. (1995) \\
\hline & & $\mathrm{UK}$ & Elliott \& Shotts (1980a) \\
\hline & & USA & Elliott \& Shotts (1980a) \\
\hline 'Shubunkin' & Carassius $5 \mathrm{p}$ & Yugoslavia & Evenberg et al. \{1982\} \\
\hline \multicolumn{4}{|l|}{ WILD FISH } \\
\hline Bream & Abramis brama & Finland & Wiklund (unpubl data) \\
\hline Chub & Leuciscus cephalus & UK & Wilson \& Holliman (1994) \\
\hline Crucian carp & Carassius carassius & Hungary & Csaba et al. (1980a) \\
\hline Dace & Leuciscus leuciscus & Finland & Hirvelä-Koski et al. (1994) \\
\hline Goldfish & Carassius auratus & $\begin{array}{l}\text { Australia } \\
\text { Canada }\end{array}$ & $\begin{array}{l}\text { Whittington et al. (1987) } \\
\text { Munkittrick \& Leatherland (1984) }\end{array}$ \\
\hline Minnow & Phoxinus phoxinus & Norway & Håstein et al. (1978) \\
\hline \multirow[t]{3}{*}{ Roach } & Rutilus rutilus & Australia & Humphrey \& Ashburner (1993) \\
\hline & & $\begin{array}{l}\text { Finland } \\
\text { Sweden }\end{array}$ & $\begin{array}{l}\text { Hirvelä-Koski et al. (1994) } \\
\text { Wichardt et al. (1989) }\end{array}$ \\
\hline & & UK & McCarthy $(1975)$ \\
\hline Rudd & Scardinuus erythrophthalmus & $\mathrm{UK}^{\mathrm{b}}$ & Gudmundsdottir et al. (1990) \\
\hline Silver bream & Blicca bjoerkna & UK & McCarthy (1975) \\
\hline \multirow{2}{*}{\multicolumn{4}{|c|}{$\begin{array}{l}\text { Order Gadiformes } \\
\text { WILD FISH }\end{array}$}} \\
\hline & & & \\
\hline Cod & Gadus morhua & $\begin{array}{l}\text { Canada }{ }^{\mathrm{a}} \\
\text { Iceland }{ }^{\mathrm{a}}\end{array}$ & $\begin{array}{l}\text { Cornick et al. (1984) } \\
\text { Guómundsdóttir et al. (1995) }\end{array}$ \\
\hline Four bearded rockling & Enchelyopus cimbrius & Denmark & Dalsgaard $(1994 b)$ \\
\hline \multirow[t]{2}{*}{ Haddock } & Melanogrammus aeglefinus & Canada ${ }^{\mathrm{d}}$ & Olivier (1992) \\
\hline & & Iceland ${ }^{\mathrm{b}}$ & Gudmundsdottir (1996) \\
\hline Tomcod & Gadus microgadus & Canada & Olivier (1992) \\
\hline Viviparous blenny & Zoarces viviparus & Baltic Sea & Wiklund (unpubl data) \\
\hline Whiting & Merlangius merlangus & Iceland & Guomundsdóttir et al. (1996) \\
\hline \multirow{2}{*}{\multicolumn{4}{|c|}{$\begin{array}{l}\text { Order Perciformes } \\
\text { FARMED FISH }\end{array}$}} \\
\hline & & & \\
\hline Common wolffish & Anarhichas lupus & Norway $^{\mathrm{a}}$ & Hellberg et al. (1996) \\
\hline Silver perch & Bidyanus bidyanus & Australia & Humphrey \& Ashburner (1993) \\
\hline Spotted wolffish & Anarhichas minor & Norway & M. Valheim (pers. comm.) \\
\hline Wrasse & Labrus berggylta & Norway & A. B. Olsen (pers. comm.) \\
\hline \multicolumn{4}{|l|}{ WILD FISH } \\
\hline Goldsinny wrasse & Ctenolabrus rupestris & $\begin{array}{l}\text { Ireland } \\
\text { Norway a }\end{array}$ & $\begin{array}{l}\text { Frerichs et al. (1992) } \\
\text { Gravningen et al. (1996) }\end{array}$ \\
\hline Perch & Perca fluviatilis & France $^{\mathrm{d}}$ & Michel (1981) \\
\hline & & Sweden & Wichardt et al. (1989) \\
\hline & & UK & Bucke et al. (1979) \\
\hline Sand-eels & $\begin{array}{l}\text { Ammodytes lancea } \\
\text { Hyperoplus lanceolatus }\end{array}$ & Denmark. $^{\circ}$ & Dalsgaard \& Paulsen (1986) \\
\hline Smallmouth bass ${ }^{c}$ & Micropterus dolomieui & USA & LeTendre et al. (1972) \\
\hline Yellow bass ${ }^{c}$ & Morone mississippiensis & USA & Bulkley (1969) \\
\hline
\end{tabular}


Table 3 (continued)

\begin{tabular}{|c|c|c|c|}
\hline Fish species & Scientific name & Country & Source \\
\hline \multicolumn{4}{|c|}{ Order Pleuronectiformes } \\
\hline \multicolumn{4}{|c|}{ FARMED FISH } \\
\hline Shotted halibut & Eopsetta grigorjewi & Japan & Nakatsugawa (1994) \\
\hline \multirow{2}{*}{ Turbot } & Scophthalmus maximus & Denmark & Pedersen et al. (1994) \\
\hline & & Norway & Gravningen \& Dydland (1991) \\
\hline \multicolumn{4}{|l|}{ WILD FISH } \\
\hline American plaice & Hippoglossoides platessoides & Canada $^{a}$ & Olivier (1992) \\
\hline \multirow[t]{2}{*}{ Dab } & Limanda limanda & Baltic Sea & Wiklund (unpubl data) \\
\hline & & Denmark & Wiklund \& Dalsgaard (1995) \\
\hline \multirow[t]{3}{*}{ Flounder } & Platichthys flesus & Denmark & Wiklund \& Dalsgaard (1995) \\
\hline & & Finland & Wiklund \& Bylund (1991) \\
\hline & & Southern Baltic Sea & Wiklund \& Dalsgaard (1995) \\
\hline Greenback flounder & Rhombosolea tapirina & Australia ${ }^{\mathrm{a}}$ & Whittington et al. (1995) \\
\hline Halibut & Hippoglossus hippoglossus & $\begin{array}{l}\text { Canada } \\
\text { Norway }\end{array}$ & $\begin{array}{l}\text { Cornick et al. (1984) } \\
\text { Gudmundsdóttir (1996) }\end{array}$ \\
\hline Plaice & Pleuronertes platessa & Denmark & Wiklund \& Dalsgaard (1995) \\
\hline Turbot & Scophthalmus maximus & Baltic Sea & Wiklund (unpubl. data) \\
\hline Order Salmoniformes & & & \\
\hline \multicolumn{4}{|l|}{ FARMED FISH } \\
\hline \multirow[t]{5}{*}{ Arctic char } & Salvelinus alpinus & Canada & Olivier (1992) \\
\hline & & Finland & Hirvelä-Koski et al. (1994) \\
\hline & & Iceland ${ }^{b}$ & Gudmundsdóttir (1996) \\
\hline & & Norway & M. Valheim (pers. comm.) \\
\hline & & Sweden & Ljungberg \& Johansson (1977) \\
\hline \multirow[t]{6}{*}{ Atlantic salmon } & Salmo salar & Canada & Paterson et al. (1980b) \\
\hline & & Faeroe Islands & Dalsgaard \& Mortensen (1988) \\
\hline & & Finland & Rintamäki \& Valtonen (1991) \\
\hline & & Iceland $^{\mathrm{b}}$ & Gudmundsdottir et al. (1990) \\
\hline & & Norway & Olsen et al. (1989) \\
\hline & & Sweden & Ljungberg \& Johansson (1977) \\
\hline \multirow[t]{3}{*}{ Brook trout } & Salvelinus fontinalis & Canada & Bullock et al. (1971) \\
\hline & & Sweden & Ljungberg \& Johansson (1977) \\
\hline & & USA & Snieszko et al. (1950) \\
\hline \multirow[t]{3}{*}{ Brown trout } & Salmo trutta m. fario & Finland & Hirvelä-Koski et al. (1994) \\
\hline & & Iceland ${ }^{b}$ & Gudmundsdóttir (1996) \\
\hline & & Sweden & Ljungberg \& Johansson (1977) \\
\hline Chum salmon & Oncorhynchus keta & Canada & Evelyn (1971) \\
\hline \multirow[t]{2}{*}{ Grayling } & Thymallus thymallus & Finland & Rintamäki \& Valtonen (1991) \\
\hline & & Sweden & Ljungberg \& Johansson (1977) \\
\hline \multirow[t]{2}{*}{ Lake trout } & Salmo trutta m. lacustris & Finland & Ojala $(1966)$ \\
\hline & & Sweden & Ljungberg \& Johansson (1977) \\
\hline Masu salmon & Oncorbynchus masou & Japan & Kimura (1969a) \\
\hline Pink salmon & Oncorhynchus gorbuscha & Japan & Kimura (1969a) \\
\hline Rainbow trout & Oncorhynchus mykiss & Canada & Olivier (1992) \\
\hline & & Finland & Hirvelä-Koski et al. (1994) \\
\hline & & South Africa & Boomker et al. (1984) \\
\hline & & Sweden & Ljungberg \& Johansson (1977) \\
\hline Sea trout & Salmo trutta m. trutta & Faeroe Islands $b$ & Gudmundsdottir (1990) \\
\hline & & Finland & Rintamäki \& Valtonen (1991) \\
\hline & & Norway ${ }^{b}$ & Pedersen et al. (1996) \\
\hline & & Sweden & Wichardt (1983a) \\
\hline Whitefish & Coregonus sp. & Finland & Hirvelä-Koski et al (1994) \\
\hline WILD FISH & & & \\
\hline Atlantic salmon & Salmo salar & Canada & Olivier (1992) \\
\hline Grayling & Thymallus thymallus & Finland & Hirvelä-Koski et al. (1994) \\
\hline Pike & Esox lucius & Finland & Wiklund $(1990)$ \\
\hline & & Sweden & Wichardt et al. (1989) \\
\hline & & $\mathrm{UK}^{\mathrm{b}}$ & Austin et al. (1989) \\
\hline Sea trout & Salmo trutta m. trutta & Scotland & Smith (1963) \\
\hline Sockeye salmon & Oncorhynchus nerka & Canada ${ }^{a}$ & Evelyn (1971) \\
\hline Order Scorpaeniforme & & & \\
\hline WILD FISH & & & \\
\hline Sablefish & Anoplopoma fimbria & Canada ${ }^{a}$ & Evelyn $(1971)$ \\
\hline "Wild fish kept in $\tan$ & uaria or net pens & & \\
\hline Not reported whethe & ated from wild or farmed fish & & \\
\hline Present identificatior & olates as atypical Aeromonas $s$ & icida is based on sl & igment production \\
\hline
\end{tabular}


In most studies the fish showed signs of disease shortly after transfer to the tanks or aquaria. However, the source of the infection usually remained unknown, and it was not definitely established whether the fish infected with atypical $A$. salmonicida harbored the pathogen at the time of capture or whether the fish were infected during transport or from the water or equipment in the tanks or aquaria (Evelyn 1971, Cornick et al. 1984, Dalsgaard \& Paulsen 1986, Whittington et al. 1995). In other studies atypical strains have been isolated from the skin (Hubbert \& Williams 1980), gills (Benediktsdōttir \& Helgason 1990), and kidney (Frerichs et al. 1992) of clinically healthy fish without any signs of disease, indicating that atypical A. salmonicida might be present in or on the fish and that stressful conditions (e.g. capture and transfer to tanks) may cause subsequent outbreaks of disease.

\section{Salmonids}

Fish belonging to different species of the family Salmonidae have frequently been reported to be infected with atypical Aeromonas salmonicida (see Table 3); increased reporting is probably due to the intensive farming of, and economical interest in, these species. More than 10 different salmonid species have been found to be infected with atypical $A$. salmonicida. There are, however, comparably few reports on the isolation of atypical strains from wild fish belonging to family Salmonidae (Evelyn 1971, Olivier 1992, HirveläKoski et al. 1994) (Table 3).

\section{GEOGRAPHICAL DISTRIBUTION}

The geographical distribution of reported isolations of atypical Aeromonas salmonicida is indicated in Table 3. Available reports suggest that atypical $A$. salmonicida strains infect fish mainly in the temperate regions of the northern hemisphere, that is, Canada, the USA, Japan, and central and northern Europe including the Nordic countries. In addition, atypical strains have been isolated from fish in southern Australia including Tasmania (Whittington et al. 1987 , Whittington et al. 1995), South Africa (Boomker et al. 1984) and from fish exported from Singapore (Whittington et al. 1995). There are also a few reports of atypical strains isolated from fish in the Mediterranean area: from carp Cyprinus carpio and goldfish Carassius auratus in former Yugoslavia (Bootsma et al. 1977 , Evenberg et al. 1982) and from goldfish in Italy (Whittington et al. 1987). To date, there is no information available about atypical $A$. salmonicida infecting fish in South America, Russia or northern Asia.
Atypical Aeromonas salmonicida strains have been isolated from fish in fresh water (Bulkley 1969, Håstein et al. 1978, Michel 1981, Whittington et al. 1987, Noga \& Berkhoff 1990, Wilson \& Holliman 1994), brackish water (Wiklund 1990, Wiklund \& Bylund 1991, Wiklund et al. 1994), as well as salt water habitats (Boomker et al. 1984, Cornick et al. 1984, Dalsgaard \& Paulsen 1986, Pedersen et al. 1994, Whittington et al. 1995, Wiklund \& Dalsgaard 1995, Hellberg et al. 1996).

\section{PATHOLOGY}

\section{Non-salmonids}

Atypical Aeromonas salmonicida infection in nonsalmonids often manifests itself predominantly as a skin infection (skin ulceration) without subsequent general septicaemia. Skin ulcerations and skin lesions on wild and farmed non-salmonid fish have been observed in connection with most disease outbreaks associated with atypical $A$. salmonicida. The best described diseases showing these symptoms are carp erythrodermatitis (CE; Fijan 1972, Bootsma et al. 1977, Csaba et al. 1980a, b, Sövényi et al. 1984, Böhm et al. 1986, Mirle et al. 1986), goldfish ulcer disease (GUD; MawdesleyThomas 1969, Elliott \& Shotts 1980a, Shotts et al. 1980, Trust et al. 1980c, Böhm et al. 1986, Whittington et al, 1987. Humphrey \& Ashburner 1993, Whittington et al. 1995), and ulcer disease of flounder (UDF) in the Baltic and the North Sea, including adjacent rivers (Nounou et al. 1981, Möller 1990, Wiklund \& Bylund 1991, Ullrich 1992, Vethaak 1992, Wiklund \& Bylund 1993, Wiklund 1994a, b, Wiklund et al. 1994, Wiklund \& Dalsgaard 1995). In addition, many other fish species have been reported to be affected by ulcerations associated with atypical $A$. salmonicida, and the pathogen is apparently involved in more disease outbreaks than previously suspected (McCarthy 1975. Håstein et al. 1978, Ohtsuka et al. 1984, Dalsgaard \& Paulsen 1986, Noga \& Berkhoff 1990, Wiklund 1990, Pedersen et al. 1994, Wilson \& Holliman 1994, Larsen \& Pedersen 1996).

In carp affected by CE, the ulcers can be found all over the body surface except on the head (Jeney \& Jeney 1995). The scales of the fish have been reported to be initially surrounded by inflammation with infiltration of inflammatory cells. The scales are subsequently shed. The epithelium and corium become necrotized with marked hyperaemia surrounding the resulting ulcer. The inflammatory cells subsequently spread into the muscle (Gayer et al. 1980, Jeney \& Jeney 1995).

Mawdesley-Thomas (1969) reported that the general health of goldfish infected with Aeromonas salmonicida was variable. Affected fish developed skin ulcers of 
varying size and depth, which could appear on any part of the body. In some specimens even the face, operculum and the eyes were affected. A marked increase in pigmentation in and around the lesions and inflammatory cells penetrating far into the surrounding musculature were observed. Some of the ulcers were secondarily infected with Saprolegnia sp. Some fish died within a few days; others showed lethargy, loss of orientation and abnormal swimming movements.

In flounder affected by UDF, the ulcers have been described as open, dark red, rounded, and superficial (Wiklund \& Bylund 1993). Ulcer size varied from small lesions ( 1 to $2 \mathrm{~mm}$ ) to large eroded areas (10 to $20 \mathrm{~mm}$ in diameter). The development of the ulcers was divided into 3 stages: (1) initially weak haemorrhage in the skin which developed into (2) a white lesion surrounded by a red rim of haemorrhagic inflammatory tissue; (3) in the final, true ulcer stage the skin tissue was eroded and the muscle tissue was exposed (Wiklund \& Bylund 1993). Unfortunately, there are no reports on histological studies of skin ulcers in flounder.

Although there is accumulating evidence that atypical Aeromonas salmonicida is the aetiological agent of CE, GUD and UDF, the subject is a matter of discussion, and under certain circumstances other (opportunistic) pathogens can be isolated. In addition to $A$. salmonicida, the aetiology of CE, GUD and UDF has been associated with Aeromonas hydrophila, Vibrio anguillarum, Flexibacter columnaris or opportunistic pathogens (Takahashi et al. 1975a, b, c, Nounou et al. 1981, Sioutas et al. 1991, Ullrich 1992, Vethaak 1992, reviewed by Wiklund $1994 \mathrm{~b})$. However, some of these studies were inadequately reported or performed and, hence, a successful isolation of atypical $A$. salmonicida strains could not be ensured. Sioutas et al. (1991) and Vethaak (1992) did not specify the incubation time when examining ulcerated carp and flounder. Slowgrowing strains of atypical $A$. salmonicida could have been overlooked due to a short incubation time. Vethaak (1992) isolated A. salmonicida from flounder, but it was not stated whether this was a typical or an atypical strain. Nounou et al. (1981) used selective or nonenriched media in the isolation procedure, thus hampering the probable isolation of fastidious atypical $A$. salmonicida from ulcerated flounder.

In American eel Anguilla rostrata, European eel Anguilla anguilla, as well as Japanese eel Anguilla japonica, atypical Aeromonas salmonicida strains have been reported to cause severe necrosis, lesions of the skin, and tissue swelling on the head of affected specimens (Iida et al. 1984, Kitao et al. 1984, 1985, Ohtsuka et al. 1984, Noga \& Berkhoff 1990, Dalsgaard 1994b). The disease in eels has thus been referred to as 'head ulcer disease' (Ohtsuka et al. 1984). A mild to severe, primarily mononuclear infiltrate was observed in the ulcers (Noga \& Berkhoff 1990). Many lesions had extensive collagen deposition, contributing to the tissue swelling. Bacterial microcolonics wcre common on the surface and within ulcerations (Noga \& Berkhoff 1990).

In addition to skin ulcerations, atypical Aeromonas salmonicida has also been associated with erosions on the mouth, varying from weak haemorrhage on the snout (sand-eels; Dalsgaard \& Paulsen 1986), and erosion of the lip (shotted halibut Eopsetta grigorjewi; Nakatsugawa 1994) to destruction of the bones in the upper and lower jaws (minnow Phoxinus phoxinus; Håstein et al. 1978) of non-salmonid fish. Additionally, haemorrhage and erosion of the fins (McCarthy 1975 , Trust et al. 1980C, Wilson \& Holliman 1994, Jeney \& Jeney 1995), with subsequent necrosis of the tail (Dalsgaard \& Paulsen 1986), and haemorrhage or lesions in the eyes (Mawdesley-Thomas 1969, Håstein et al. 1978) have been associated with infections caused by atypical A. salmonicida. Hyperplasia or proliferation of the gills sometimes containing bacterial colonies has been reported (Mawdesley-Thomas 1969, Morrison et al. 1984). In histological studies, the ulcers showed pathological changes with oedema, distortion of the scales, hyperaemia, haemorrhage, leucocytic infiltration and the presence of fibroblast-like cells often causing granulomatous tissue in the dermis as well as in the spleen and the kidney (Håstein et al. 1978, Morrison et al. 1984).

In non-salmonids there are few reports on signs of pathological disease in internal organs of fish infected with atypical Aeromonas salmonicida. Congested and dark kidneys, spleens and gills were detected in goldfish naturally infected with atypical $A$. salmonicida. Additionally, enlargement of the hepatocytes, degenerative changes in the kidney, congestion and in some cases hyperplasia in the spleen were observed (Mawdesley-Thomas 1969). Pathological signs of disease in the intestine (haemorrhage and hyperaemia) have been observed in captive sand-eels (Dalsgaard \& Paulsen 1986) and farmed common wolffish Anarhichas lupus (Hellberg et al. 1996). Additionally, haemorrhages in the liver and in the musculature of infected sand-eels have been reported (Dalsgaard \& Paulsen 1986). In infection experiments with atypical A. salmonicida isolated from cod, degenerative changes, accumulated leucocytes, and cyst formations were seen in the spleen and kidney of infected cod, while in Atlantic salmon Salmo salar the injected bacteria caused no cellular host reaction except for the presence of necrotic muscle fibers at the injection site (Morrison et al. 1984). In farmed wolffish, neither a corresponding leucocyte reaction nor fibroblast encystment of atypical A. salmonicida was observed (Hellberg et al. 1996). However, Bulkley (1969), McCarthy (1975), Håstein et al. (1978), Michel (1981), Wilson \& 
Holliman (1994), and Jeney \& Jeney (1995) reported that macroscopical signs of disease in internal organs of fish (silver bream Blicca bjoerkna, carp, minnow, perch Perca fluviatilis, yellow bass Morone mississippiensis) infected with atypical $A$. salmonicida were not observed, although Jeney \& Jeney (1995) stated that a slight fatty degeneration was sometimes visible in carp affected by carp erythrodermatitis. According to Fijan (1972), the internal organs of carp affected with small ulcers appeared normal, but in the terminal stages fluid accumulation was found in the abdominal cavity and the internal organs were oedematous. In several studies no indication of pathological signs in internal organs of non-salmonids infected with atypical $A$. salmonicida have been reported (Trust et al. 1980c, Whittington et al. 1987, Noga \& Berkhoff 1990, Wiklund 1990, Wiklund \& Bylund 1993, Pedersen et al. 1994, Wiklund \& Dalsgaard 1995).

\section{Salmonids}

In salmonids different atypical Aeromonas salmonicida strains have been associated with different pathological gross signs. Wichardt (1983a) concluded that the signs of disease in sea trout Salmo trutta m. trutta, which were caused by pigment-producing atypical $A$. salmonicida, more closely resembled those induced by achromogenic variants of atypical $A$. salmonicida than those caused by typical strains. In contrast, Rintamäki \& Valtonen (1991) found pigment-producing atypical A. salmonicida caused signs of disease in salmonids (mainly brown trout Salmo trutta m. fario and Atlantic salmon) that were similar to those caused by typical $A$. salmonicida but different from those caused by achromogenic variants of atypical $A$. salmonicida. The achromogenic strains caused mainly skin ulcerations and other external or internal signs of disease were not detectable. According to Groman et al. (1992), both A. salmonicida subsp. nova and typical A. salmonicida produced similar signs of disease in salmon, i.e. lethargy, aimless swimming, respiratory distress, fin erosion and haemorrhagic cutaneous and muscular lesions. In some of the disease outbreaks in salmonids caused by atypical A. salmonicida strains, ulcerations in the infected fish were reported (Snieszko et al. 1950, Paterson et al. 1980b, Boomker et al. 1984, Rintamäki \& Valtonen 1991). Ulcerations were characteristically observed in disease outbreaks in brook trout Salvelinus fontinalis associated with Hemophilus piscium (Snieszko et al. 1950, Bullock et al. 1971), now classified as atypical A. salmonicida (Paterson et al. 1980a). Histologically, cellular infiltration, degenerative changes in the epithelial and superficial muscle cells and considerable tissue destruction have been observed in ulcerations of rainbow trout Oncorhynchus mykiss caused by atypical $A$. salmonicida. However, tissue reaction or attempts at regeneration were not observed (Boomker et al. 1984).

Haemorrhages in the gills, liver, heart, intestine as well as in the peritoneal cavity of sea trout and lake trout Salmo trutta m. lacustris have been reported (Ojala 1966, Wichardt 1983a). Boomker et al. (1984) observed the presence of a few gross changes in internal organs, like slight splenomegaly, discoloration of the liver and enlargement of the kidney of rainbow trout infected with atypical A. salmonicida. Microscopically, the spleen and the liver were congested and in the kidney slight vasculitis and early degeneration of tubular epithelium were encountered. Bacterial colonies were scarce and present only in sections of the skin.

The few signs of disease reported to be present in internal organs of fish indicate that atypical Aeromonas salmonicida seldom colonizes those organs. This conclusion is in accordance with the fact that atypical $A$. salmonicida is only occasionally isolated from the internal organs of fish with an ulcerative infection (see 'Isolation' and Table 5). Why the organism is retained at the site of the local skin lesion is unknown, but it might be a result of the effects of local inflammation and the host's immune response. Certainly there are also differences in the invasive capacity between different atypical isolates. More detailed studies on the infective mechanisms of different atypical strains and corresponding immune response in the host are needed.

\section{MORTALITY}

\section{Wild fish}

Epizootics, occasionally with high mortality, have been observed in wild fish in connection with the isolation of atypical Aeromonas salmonicida (Table 4). However, for practical reasons the mortality rate for epizootics in wild fish has seldom been presented (McCarthy 1975). Additionally, the relationship between the mortality recorded and the isolated atypical A. salmonicida strains has not always been properly established (Bucke et al. 1979). High mortality in wild fish, suggested to be caused by atypical strains, has been described among yellow bass (Bulkley 1969), silver bream (McCarthy 1975), minnow (Håstein et al. 1978), and perch (Michel 1981; strains subsequently identified as a likely atypical $A$. salmonicida, C. Michel pers. comm.) (Table 4). In some of these cases, inadequate nutrition (Bulkley 1969), transport of live fish (McCarthy 1975), or low water associated with spawn- 
Table 4. Mortality rates in wild fish species and farmed salmonids associated with atypical Aeromonas salmonicida

\begin{tabular}{|c|c|c|c|c|}
\hline Fish species & Country & Mortality & Year & Source \\
\hline \multicolumn{5}{|l|}{ Wild fish species } \\
\hline Silver bream & UK & $25 \%$ morbidity & & McCarthy (1975) \\
\hline Perch & UK & $>98 \%$ & 1976 & Bucke et al. (1979) \\
\hline Yellow bass & USA & Considerable & & Bulkley (1969) \\
\hline Minnow & Norway & Mass mortality & & Håstein et al. (1978) \\
\hline Perch & France & Mass mortality & & Michel (1981) \\
\hline \multicolumn{5}{|l|}{ Farmed salmonids } \\
\hline Sea trout & Sweden & $60-65 \%$ & 1983 & Wichardt (1983b) \\
\hline Atlantic salmon & Canada & $\sim 50 \%$ & 1974 & Paterson et al. (1980b) \\
\hline Rainbow trout & South Africa & $30 \%$ & 1981 & Boomker et al. (1984) \\
\hline Atlantic salmon & Canada & $>25 \%$ & 1991 & Groman et al. (1992) \\
\hline Different species & Iceland & $15-25 \%$ & & Guòmundsdóttir et al. (1995) \\
\hline Sea trout & Finland & $2-20 \%$ & 1988 & Rintamäki \& Valtonen (1991) \\
\hline Salmon & Faroe Islands & $7 \%$ & 1986 & Dalsgaard \& Mortensen (1988) \\
\hline
\end{tabular}

ing season (Håstein et al. 1978), which all may cause stressful conditions for the fish, were suggested as the primary cause of the infection with atypical $A$. salmonicida and subsequent heavy mortality observed. In some studies of ulcerated fish, mortality in the affected population has not been reported (Wiklund 1990, Wiklund \& Bylund 1993, Wiklund \& Dalsgaard 1995). However, low mortality in a fish population, whatever the reason, will most probably remain undetected. Low numbers of weak and moribund fish will be eliminated due to predation by fish, birds and mammals.

\section{Farmed fish}

In farmed fish high cumulative mortality has been reported in several studies (Table 4). Wichardt (1983b) reported very high mortality (60 to $65 \%$ ) in farmed sea trout in one farm in Sweden due to atypical Aeromonas salmonicida infections during unfavourable environmental conditions. In farmed Atlantic salmon in Canada, $50 \%$ cumulative mortality was observed in 1974 (Paterson et al. 1980b). In 1991 over $\$ 500000$ in potential sales were lost during disease outbreaks caused by atypical $A$. salmonicida, which was considered to be the major economic constraint to the commercial salmonid culture in the area (Groman et al. 1992). In Iceland atypical $A$. salmonicida infections in farmed fish have caused losses equal to $15-25 \%$ of the total slaughter production (Guðmundsdóttir et al. 1995). In general, however, the mortality due to atypical strains has generally stayed low although occasional mortality up to $20 \%$ (Rintamäki \& Valtonen 1991), $30 \%$ (Boomker et al. 1984) and 35\% (calculated from Pedersen et al. 1994) have been reported (Table 4).

The mortality in carp caused by atypical Aeromonas salmonicida has been found to reach $25 \%$ in pond culture (Sövényi 1986). However, it has been suggested that the mortality in carp populations was caused by invasion of opportunistic pathogens, facilitated by the immunosuppressive substances released by atypical A. salmonicida (Evenberg et al. 1986, Pourreau et al. 1986, Sövényi et al. 1988).

\section{ISOLATION}

While the isolation of typical Aeromonas salmonicida is mostly a standard procedure and the cells readily grow on basic isolation agar, the recovery of atypical $A$. salmonicida is more difficult. Fastidious, slow-growing strains of atypical $A$. salmonicida (Bullock et al. 1971, Ishiguro et al, 1986, Wiklund \& Bylund 1991, Olivier 1992, Pedersen et al. 1994, Wiklund \& Dalsgaard 1995) have been reported to require agar supplemented with blood or serum for isolation and further cultivation (Paterson et al. 1980b, Ishiguro et al. 1986, Olivier 1992, Wiklund et al. 1994, Wiklund \& Dalsgaard 1995). McCarthy (1977) reported that tryptone soya agar was superior to blood-containing medium for the isolation of atypical as well as typical $A$. salmonicida. However, this view was not confirmed by any comparative analysis, and it represented merely an opinion based on laboratory experience. Austin (1993) found that atypical strains did grow on blood agar, but not on brain-heart infusion agar or tryptone soya agar at isolation, but subcultures grew well on all 3 media. It has been suggested that the incidence of atypical A. salmonicida as a pathogen of different fish species may have been underestimated in studies using agar medium without blood (Paterson et al. 1980b).

Several studies show that atypical Aeromonas salmonicida is predominantly isolated from skin ulcers and only occasionally from visceral organs of fish of different species (Table 5). This has been observed in investigations of ulcer disease of brook trout (Snieszko 
Table 5. Isolation (\% of total number of fish examined) of atypical Aeromonas salmonicida from ulcerations and visceral organs of different fish species. nr: atypical A. salmonicida isolated but exact number of isolates not reported

\begin{tabular}{|llcccc|}
\hline Fish species & Country & $\begin{array}{c}\text { No. of } \\
\text { fish examined }\end{array}$ & $\begin{array}{c}\text { Isolation from } \\
\text { ulcerations (\%) }\end{array}$ & $\begin{array}{c}\text { Isolation from } \\
\text { visceral organs (\%) }\end{array}$ & Source \\
\hline Flounder & Finland & 162 & 54 & 2 & Wiklund \& Bylund (1991) \\
Chub & UK & 14 & 64 & 0 & Wilson \& Holliman (1994) \\
Cod & Canada & 22 & 77 & 22 & Cornick et al. (1984) \\
Goldfish & Japan, UK, USA & 83 & 77 & 26 & Elliot \& Shotts (1980a) \\
Flounder & Denmark \& southern & 16 & 81 & 0 & Wiklund \& Dalsgaard (1995) \\
Roach & Baltic Sea & 75 & 95 & 24 & Hubbert \& Williams (1980) \\
American eel & UK & 20 & $n r$ & 0 & Noga \& Berkhoff (1990) \\
aNumber of fish examined for infection in visceral organs $=31$ & & \\
\hline
\end{tabular}

et al. 1950), CE (Csaba et al. 1980a, Sövényi et al. 1988, Austin 1993), GUD (Elliott \& Shotts 1980a, Whittington et al. 1987, Austin 1993), head ulcer disease of eel (Noga \& Berkhoff 1990), ulcerations in perch (Michel 1981), ulcerated cod kept in tanks (Cornick et al. 1984), ulcerations in roach Rutilus rutilus (Hubbert \& Williams 1980, Austin 1993), and skin ulcerations in different wild flatfish species like flounder, dab Limanda limanda, plaice Pleuronectes platessa and turbot Scophthalmus maximus from the Baltic Sea and the North Sea (Wiklund \& Bylund 1991, Wiklund \& Dalsgaard 1995) (Table 5). In other studies isolation of atypical $A$. salmonicida has successfully been achieved from internal organs of non-salmonid wild fish kept in tanks or net-pens (Dalsgaard \& Paulsen 1986, Traxler \& Bell 1988).

In farmed fish, atypical Aeromonas salmonicida is often readily isolated from internal organs as well as from ulcers. This has been shown for farmed turbot in Denmark, where atypical $A$. salmonicida was isolated from external ulcers and kidneys of ulcerated specimens (Pedersen et al. 1994). Elliott \& Shotts (1980a) reported that atypical $A$. salmonicida was more prevalent in kidneys of goldfish which had ulcerations in the late stage of development than in goldfish with ulcers in the early or intermediate stage of development.

In several studies it was observed that atypical Aeromonas salmonicida could not be isolated from the ulcers of all examined ulcerated fish (Table 5). Additionally, atypical $A$. salmonicida was isolated mainly from lesions or ulcers in an early stage of development, and more seldom from chronic, terminal or healing lesions (Elliott \& Shotts 1980a, Whittington et al. 1987, Wiklund \& Dalsgaard 1995). Generally, in later developmental stages the ulcers had often been invaded by opportunistic pathogens and contaminating water microorganisms such as motile Aeromonas sp., Pseudomonas sp. and Saprolegnia sp. (Bootsma et al. 1977, Elliott \& Shotts 1980a, Noga \& Berkhoff 1990). The slow growth of atypical A. salmonicida, overgrowth by other bacteria, and/or growth suppression of $A$. salmonicida by contaminants may have contributed to the failure to isolate this pathogen (Bootsma et al. 1977, Elliott \& Shotts 1980a, Bullock et al. 1983, Humphrey \& Ashburner 1993).

In conclusion it seems essential to perform bacterial isolation on recently developed skin ulcerations as well as on the internal organs of fish, using agar supplemented with blood or serum, in order to make a proper identification of the aetiologic agent of the skin ulcer disease, especially in wild fish.

\section{PATHOGENICITY}

The pathogenicity of different atypical Aeromonas salmonicida strains seems to be highly variable (Table 6). However, comparison of the virulence of the examined strains is difficult due to the varying methods used in the different studies. The assessment of virulence has been performed on different fish species, and the administration of the bacteria by different routes of challenge (e.g. intraperitoneal, intramuscular, subcutaneous, bath and rubbing into disrupted skin); the amount of administered bacteria has varied greatly, and several studies did not report whether the strain tested was freshly isolated or passed on artificial media (agar) once or several times before the challenge experiment was performed. In some studies the injected amount of bacteria was not reported (Bucke 1980, Michel 1981, Sövényi \& Ruttkay 1986, Sövényi et al. 1988). The age and the genetic strain of the fish (e.g. carp) can also significantly affect the resistance against bath challenge with atypical $A$. salmonicida (Wiegertjes et al. 1993). Additionally, the nutritional status of the fish (e.g. Arctic char Salvelinus alpinus, carp, grayling Thymallus thymallus) and the feeding regime have also been shown to affect the resistance to challenge with atypical $A$. salmonicida (Sövényi \& Ruttkay 1986, Pylkkö 1993). 
Table 6. Aeromonas salmonicida. Virulence of atypical A salmonicida strains isolated from various fish species. i.p.: intraperitoneal; i.m.: intramuscular; s.c.: subcutaneous; MLD: minimum lethal dose

\begin{tabular}{|c|c|c|c|c|c|}
\hline $\begin{array}{l}\text { Host fish } \\
\text { species }\end{array}$ & $\begin{array}{l}\text { Challenged } \\
\text { fish species }\end{array}$ & $\begin{array}{l}\text { Challenge } \\
\text { mode }\end{array}$ & $\begin{array}{l}\text { Injected amount } \\
\text { of bacteria }\end{array}$ & $\begin{array}{c}\text { Mortality or } \mathrm{LD}_{50} \\
\text { (no. of dead fish/no. of infected) }\end{array}$ & Source \\
\hline Silver bream & Rainbow trout & i.p. & $1.7 \times 10^{9}(\mathrm{MLD})$ & Not reported & McCarthy (1975) \\
\hline Minnow & Minnow & i.p. & $6 \times 10^{8}$ & $5 / 5$ & Håstein et al. (1978) \\
\hline Turbot & Atlantic salmon & i.p. & $1.3 \times 10^{8}$ & $0 / 6$ & Pedersen et al. (1994) \\
\hline Wrasse & Atlantic salmon & $\begin{array}{l}\text { i.p. } \\
\text { Bath }\end{array}$ & $\begin{array}{l}1.4 \times 10^{6} \\
4.7 \times 10^{6}\end{array}$ & $\begin{array}{l}0 / 10 \\
0 / 10\end{array}$ & $\begin{array}{l}\text { Frerichs et al. (1992) } \\
\text { Frerichs et al. (1992) }\end{array}$ \\
\hline Sand eels & Rainbow trout & i.p. & $8.0 \times 10^{6}$ & $5 / 10$ & Dalsgaard \& Paulsen (1986) \\
\hline $\begin{array}{l}\text { Flounder } \\
\text { Flounder } \\
\text { Flounder } \\
\text { Flounder }\end{array}$ & $\begin{array}{l}\text { Flounder } \\
\text { Rainbow trout } \\
\text { Roach } \\
\text { Bleak }\end{array}$ & $\begin{array}{l}\text { i.p. } \\
\text { i.p. } \\
\text { i.p. } \\
\text { i.p. }\end{array}$ & $\begin{array}{l}3.7 \times 10^{6 \mathrm{a}} \\
3.7 \times 10^{7 \mathrm{a}} \\
0.8 \times 10^{3 \mathrm{~d}} \\
0.8 \times 10^{3 \mathrm{a}}\end{array}$ & $\begin{array}{l}4 / 9 \\
4 / 12^{\mathrm{b}} \\
4 / 5^{\mathrm{b}} \\
3 / 4^{\mathrm{b}}\end{array}$ & $\begin{array}{l}\text { Wiklund (1995b) } \\
\text { Wiklund (1995b) } \\
\text { Wiklund (1995b) } \\
\text { Wiklund (1995b) }\end{array}$ \\
\hline Cod & Atlantic sălmon & $\begin{array}{l}\text { i.m. } \\
\text { i.p. }\end{array}$ & $\begin{array}{l}2.8 \times 10^{6} \\
2.0 \times 10^{8}\end{array}$ & $\begin{array}{l}4 / 4 \\
5 / 5\end{array}$ & $\begin{array}{l}\text { Cornick et al. (1984) } \\
\text { Cornick et al. (1984) }\end{array}$ \\
\hline Goldfish & Goldfish & i.p., i.m., s.c. & $1 \times 10^{5}$ & $10 / 10$ & Elliot \& Shotts (1980b) \\
\hline Goldfish & Goldfish & i.m. & $1.0 \times 10^{4}$ & $8 / 8$ & Trust et al. (1980c) \\
\hline $\begin{array}{l}\text { Cyprinid } \\
\text { Cyprinid }\end{array}$ & $\begin{array}{l}\text { Goldfish } \\
\text { Rainbow trout }\end{array}$ & $\begin{array}{l}\text { i.m. } \\
\text { i.m. }\end{array}$ & $\begin{array}{l}10^{3} \\
10^{3}\end{array}$ & $\begin{array}{l}7 / 10 \\
6 / 10\end{array}$ & $\begin{array}{l}\text { Austin (1993) } \\
\text { Austin (1993) }\end{array}$ \\
\hline Wrasse & Goldsinny wrasse & i.p. & $5 \times 10^{2}$ & 27 and $28 / 30$ & Gravningen et al. (1996) \\
\hline Japanese eel & Japanese eel & i.m. & $1.0 \times 10^{2 a}$ & $\mathrm{LD}_{50}<100^{c}$ & Ohtsuka et al. (1984) \\
\hline Pacific herring & Pacific herring & i.p. & $1.4 \times 10^{\mathrm{a}}$ & $\mathrm{LD}_{50}=14(10 / 20)$ & Traxler \& Bell (1988) \\
\hline Goldfish & Atlantic salmon & i.p. & $3.0 \times 10^{\circ}$ & $\mathrm{LD}_{50}=3$ & Carson \& Handlinger (1988) \\
\hline Goldfish & Atlantic salmon & i.p. & $<10$ & $\mathrm{LD}_{50}=7.4 \times 10^{-3 \mathrm{~d}}$ & Whittington \& Cullis (1988) \\
\hline Goldfish & Brown trout & i.p. & $<10$ & $L D_{50}=3.0 \times 10^{-2 d}$ & Whittington \& Cullis (1988) \\
\hline Goldfish & Brook trout & i. $p$. & $<10$ & $\mathrm{LD}_{50}=3.7 \times 10^{2} \mathrm{a}$ & Whittington \& Cullis (1988) \\
\hline Goldfish & Rainbow trout & i.p. & 37 & $\mathrm{LD}_{s 0}=6.4 \times 10^{3} \mathrm{~d}$ & Whittington \& Cullis (1988) \\
\hline
\end{tabular}

In some studies the virulence of isolated strains was tested on several fish species (Bucke 1980, Michel 1981, Whittington \& Cullis 1988, Austin 1993, Wiklund 1995b). Some of the examined strains were pathogenic only for the original host and not for other fish species challenged (Michel 1981, Wiklund 1995b), while in other studies the examined strain was pathogenic for several fish species (Bucke 1980, Whittington \& Cullis 1988, Austin 1993). Michel (1981) found that an atypical strain isolated from perch was non-pathogenic to carp, possibly pathogenic to rainbow trout and pathogenic to perch when injected intramuscularly. Wiklund (1995b) reported an atypical A. salmonicida strain isolated from flounder to be weakly pathogenic for flounder and non-pathogenic for rainbow trout. Additionally, mortality among challenged roach and bleak Alburnus alburnus occurred, but the injected pathogen could not be re-isolated; instead other bacteria including Aeromonas sp., Pseudomonas sp. and Enterobacteria were isolated. It was suggested that the injected atypical $A$. salmonicida strain caused an immunosuppressive effect on the challenged fish, allowing opportunistic pathogens to invade the fish (Wiklund 1995b).
Evenberg et al. (1986) concluded that the pathogenesis of CE caused by atypical Aeromonas salmonicida is characterised by a state of immune suppression in the infected fish. This may explain why opportunistic pathogens such as Aeromonas hydrophila, Pseudomonas sp., Vibrio sp. and Vibrio anguillarum can be isolated from internal organs of moribund, seriously ulcerated fish or from fish injected with atypical strains (Csaba et al. 1980a, Cornick et al. 1984, Evenberg et al. 1986, Wiklund 1995b, Gravningen et al. 1996). The cause of a possible immune suppression in fish infected with atypical $A$. salmonicida could be strain specific, because in other experimental studies invasion of opportunistic pathogens has not been observed in injected fish (Dalsgaard \& Paulsen 1986). In infection experiments on carp, opportunistic pathogens (previously isolated from ulcers) failed to produce ulcers in injected fish (Csaba et al. 1980a, Evenberg et al. 1986). In another study, A. hydrophila, isolated from ulcerated carp, produced clinical and pathological disease signs identical to $C E$, but the amount of bacteria injected or rubbed into scarified skin of carp was rather high $\left(3.4 \times 10^{9}\right.$ bacteria) (Sioutas et al. 1991), making the experimental evidence questionable. Elliott \& 
Shotts (1980b) reported that an anaerogenic member of the A. hydrophila complex, isolated from ulcers of diseased goldfish, did not produce ulcerations or mortality in bath challenged goldfish at a concentration of $7.2 \times 10^{6}$ colony-forming units (CFU) $\mathrm{ml}^{-1}$.

In infection experiments Bucke (1980) found that a weakly pigment-producing strain of Aeromonas salmonicida was more virulent for several fish species (brown trout, carp, goldfish, roach, rudd Scardinius erythrophthalmus and perch) than a non-pigmented strain of A. salmonicida. Unfortunately, the amount of bacteria injected was not reported. The different numbers of cells of the 2 strains injected into the fish could explain the difference in the virulence observed. Additionally, it was reported that a weakly pigmented variant of A. salmonicida could be experimentally transferred by co-habitation from infected brown trout to several fish species such as brown trout, carp, goldfish and roach (Bucke 1980).

Some strains of atypical Aeromonas salmonicida isolated from non-salmonids were reported as extremely virulent (Ohtsuka et al. 1984, Carson \& Handlinger 1988, Traxler \& Bell 1988, Whittington \& Cullis 1988), with calculated $10 \mathrm{~d} \mathrm{LD}_{50}$ values as low as $7.4 \times 10^{-3}$ CFU by intraperitoneal injection (i.p.) (Whittington \& Cullis 1988). The $\mathrm{LD}_{50}$ value in this study was estimated, by regression analysis, to be the dose for which the median lifetime of challenged fish was $10 \mathrm{~d}$. As the atypical strain used in the experiments autoagglutinated in broth, 1 CFU consisted of a clump of bacteria, which accounts for the $\mathrm{LD}_{50}$ values that were less than 1 unit (Whittington \& Cullis 1988). Other examined strains seemed to be totally non-virulent as determined in injection experiments (Pedersen et al, 1994, MCCarthy 1975) (Table 6).

In many studies the virulence of atypical strains isolated from non-salmonid fish was assessed on fish used for farming, mainly rainbow trout or Atlantic salmon, while the virulence for the host fish species was not determined (Table 6). The explanation for this could be the need to gain knowledge about the possible spread of the disease from wild fish to the more economically important farmed fish. Tested atypical Aeromonas salmonicida strains isolated from non-salmonids seem to be non-virulent or low-virulent for salmonids (Table 6), except for strains isolated from goldfish in Australia, which have proved to be extremely virulent by i.p. injection of different salmonids (Carson \& Handlinger 1988, Whittington \& Cullis 1988). However, in experiments performed simultaneously with i.p. injection, the atypical strain was not transmitted via water from the injected fish to Atlantic salmon and rainbow trout kept in the same tanks as the infected fish (within-tank control or co-habitation) but was transmitted to a low number of brown trout and brook trout. This indicates that the invading capacity of the highly pathogenic (at i.p. injection) strain tested through the water, into salmonids, was rather limited, although Whittington \& Cullis (1988) concluded that the degree of bacterial contamination of atypical A. salmonicida of the tank environment was probably low and that the low concentrations were infective. Unfortunately, no studies on the concentration of atypical $A$. salmonicida in the water were done, so the above conclusion is based more on assumption than on fact. Additionally, in bath experiments, injection (bacterial concentrations: $2.0 \times$ $10^{5}$ to $2.0 \times 10^{6} \mathrm{CFU} \mathrm{ml^{-1 }}$ ) with the same highly pathogenic atypical strain as used for i.p. resulted in low mortality with challenged Atlantic salmon and rainbow trout, but high mortality with brown trout and brook trout. The co-habitation and bath experiments probably give a better estimate of the virulence and invasive capacity of the tested pathogen than the injection experiments. In a similar experiment done with another atypical strain isolated from ulcerated goldfish high mortality was obtained with i.p. injection $\left(\mathrm{LD}_{50}=\right.$ $3 \mathrm{CFU})$ as well as bath challenge $\left(8.0 \times 10^{5} \mathrm{CFU} \mathrm{ml}^{-1}\right)$ of Atlantic salmon (Carson \& Handlinger 1988). Whittington \& Cullis (1988) found that an atypical strain isolated from goldfish could establish a carrier state in i.p.-injected Atlantic salmon. These authors concluded that outbreaks of furunculosis in salmonid fish will occur if the tested strain of atypical $A$. salmonicida is transmitted from goldfish to salmonids.

Although atypical Aeromonas salmonicida has been isolated from several salmonid fish species (Table 3), there are surprisingly few reports on the virulence of the isolated strains. Olivier (1992) reported that strains (subsp. nova) isolated from salmonids in Newfoundland, Canada, were highly pathogenic $\left(\mathrm{LD}_{50}<100 \mathrm{bac}\right.$ teria) for juvenile Atlantic salmon and brook trout.

Unfortunately, several virulence and transmission studies of atypical Aeromonas salmonicida strains were done by injecting the pathogen into the fish (Table 6), which does not give a good picture of the infection capacities of the examined bacteria. The technique using application of bacteria into scarified skin has been applied mainly in the examination of $\mathrm{CE}$ (Bootsma et al. 1977, Csaba et al. 1980a, Gayer et al. 1980, Mirle et al. 1986). However, the amount of bacteria applied to the scarified skin is difficult to control using this method, and observed differences in virulence (40 to $100 \%$ ) of examined strains (Bootsma et al. 1977 ) could be explained by the use of different concentrations of the organisms tested. In the analysis of GUD and UDF, abrasion of the skin and bathing in a bacterial suspension of $A$. salmonicida has been performed in different studies. The concentration of bacteria in the suspension has often been rather high $\left(2 \times 10^{5}\right.$ to $4.3 \times 10^{7} \mathrm{CFU} \mathrm{m}^{-1}$ ) (Elliott \& Shotts $1980 \mathrm{~b}$, 
Carson \& Handlinger 1988, Whittington \& Cullis 1988 , Wiklund 1995b). A method using micro-injection, with Hamilton syringe, of a small amount of bacteria has been used as a compromise between scarification technique and immersion route (Evenberg et al. 1986 , Evenberg et al. 1988). However, in order to obtain an appropriate description of the virulence of atypical strains, future investigations on this issue need to use other methods like co-habitation, which so far has been employed only in a few studies on the pathogenicity of atypical A. salmonicida (Bucke 1980, Whittington \& Cullis 1988).

\section{VIRULENCE FACTORS}

Present knowledge about virulence factors in atypical strains is rather limited compared to knowledge about typical strains of Aeromonas salmonicida. The presence of extracellular products (ECPs) including proteases, A-layer of the cell wall, and iron-uptake mechanisms of atypical strains have been described in several studies. ECPs from atypical strains have been examined by Pol et al. (1980), Hastings \& Ellis (1985), Evenberg et al. (1988), Gudmundsdottir et al. 1990, and Gudmundsdóttir (1996). Pol et al. (1980) reported that crude ECP of an atypical $A$. salmonicida strain was lethal for carp, but the nature of the toxin(s) was not determined. They concluded that ulcers occurring in connection with CE are partly or exclusively caused by a bacterial toxin produced by atypical $A$. salmonicida. Evenberg et al. (1988) found that the lethality of cellfree culture supernatants of atypical A. salmonicida for carp varied significantly depending on the composition of the growth medium and incubation time. The mortality of the challenged fish ranged from zero (over $10 \mathrm{~d})$ to death within $48 \mathrm{~h}$. Hastings \& Ellis (1985) examined an atypical strain from Iceland which did not produce any detectable haemolysin or gelatinase and, in contrast to typical strains, had caseinase properties comparable to those of a metallo-protease. Subsequently, Gudmundsdottir et al. (1990) reported that a metallo-protease with a molecular weight of approximately $20 \mathrm{kDa}$ was the major extracellular lethal toxin of atypical strains isolated from salmonids in Iceland. The $24 \mathrm{~h} \mathrm{LD}_{50}$ value of the protease was $0.03 \mu \mathrm{g}$ protein $\mathrm{g}^{-1}$ fish. This protease was different from the 2 extracellular proteases (P1 and P2) described from A. salmonicida subsp. salmonicida. In contrast, strains isolated from cyprinids (goldfish, carp, and rudd) did not produce this metallo-protease (Gudmundsdottir et al. 1990). In a recent study, 25 atypical A. salmonicida strains showed significant differences in the production of extracellular proteases (Gudmundsdóttir 1996). Five different protease groups among the examined atypical strains were detected, while the examined typical strains formed a homogenous, single protease group. The results clcarly indicate that with respect to extracellular proteases the atypical strains also form a very heterogeneous group. Gudmundsdóttir (1996) concluded that exoprotease production appeared to be strongly associated with geographical location of the host rather than the host fish species itself.

A relationship between the presence of an extracellular A-layer, external to the cell wall of atypical and typical Aeromonas salmonicida, and virulence has been suggested (Kay et al. 1981, Evenberg et al. 1988, Austin \& Austin 1993). However, the close association between virulence and the presence of A-layer in typical strains is still being debated, and there are reports of non-virulent isolates possessing an A-layer and virulent isolates with no detectable A-layer (Ellis et al. 1988, Olivier 1990, Austin \& Austin 1993). A-layerpossessing as well as A-layer-deficient atypical $A$. salmonicida strains have been isolated from different fish species (Trust et al. 1980a, Kay et al. 1981, Evenberg \& Lugtenberg 1982, Evenberg et al. 1982, Chart et al. 1984, Kay et al. 1984, Pedersen et al. 1994, Wiklund et al. 1994). Detailed investigations on the virulence of A-layer-possessing and-deficient atypical strains have not been performed, but as previously indicated the virulence of different atypical strains can be host-specific and the virulence of a certain strain has to be assessed on the same fish species from which the examined strain was originally isolated (Table 6).

Bacteria have an absolute requirement for iron, and a bacterial pathogen must possess high-affinity ironuptake mechanisms which can compete with the ironbinding proteins (such as transferrin) in the serum and extracellular fluids of the host. Such mechanisms include the production of siderophores and the induction of transferrin-binding proteins under conditions of iron restriction. Siderophore production has not been observed in atypical strains (Chart \& Trust 1983, Hirst et al. 1991), and iron-uptake has been suggested to be performed by a probable proteolytic degradation of transferrin bound iron by an extracellular metalloprotease (Hirst \& Ellis 1996). A probable correlation between established protease groups (Gudmundsdóttir 1996) and uptake of iron might explain the large variations in virulence observed in different atypical strains (Table 6). However, future research will hopefully resolve this issue. The utilisation of haem-bound sources of iron have been reported to be A-layer dependent both in atypical and typical Aeromonas salmonicida (Hirst et al. 1994). Also, the utilisation of haem-bound iron by atypical A. salmonicida indicated that the mechanism of haem utilisation was not siderophore-mediated, due to the lack of siderophores in atypical strains (Hirst et al. 1991). 


\section{ECOLOGY}

Compared to typical Aeromonas salmonicida (Michel \& Dubois-Darnaudpeys 1980, Allen-Austin et al. 1984, Rose et al. 1990, Morgan et al. 1991, Effendi \& Austin 1994, Husevåg 1994, Ferguson et al. 1995), there is limited information available about the ecology, spread and survival of atypical strains in water (Evelyn 1971, Wiklund 1995a). Evelyn (1971) found that an atypical strain isolated from sablefish survived better in sea water than in fresh water (distilled or tap water). The addition of peptone to the sea water extended the survival time significantly. Wiklund (1995a) examined the survival of atypical $A$. salmonicida (isolated from ulcerated flounder from brackish water) under laboratory conditions in glass bottles (microcosms) containing sterilised water and sediment. In sterilised water the examined strains showed better survival at $4^{\circ} \mathrm{C}$ than at $15^{\circ} \mathrm{C}$. In contrast, in water and sediment slightly increased survival was observed at $15^{\circ} \mathrm{C}$ compared to $4^{\circ} \mathrm{C}$. The strains tested showed the highest survival in brackish water ( $\mathrm{S}=$ $6.4 \pm 0.5 \%$ ) compared to fresh water or salt water ( $\mathrm{S}=30 \%$ ). Wiklund (1995a) concluded that bacteria shed from ulcers of flounder may survive in the bottom sediment of brackish water environments in excess of $60 \mathrm{~d}$. The sediment can thus act as a reservoir for the pathogen, facilitating the spread of the infection, although the question of whether or not the virulence of the pathogen was preserved was not examined (Wiklund 1995a). Although the atypical strains isolated from ulcerated flounder have been reported to be fastidious, requiring serum or blood when cultivated on artificial agar plates (Wiklund \& Dalsgaard 1995), their survival in nutrient-limited conditions (sediment and brackish water) was clearly extended. However, these survival studies were done in sterilised water in microcosms, without any exchange of nutrients and waste products or interaction between the bacteria tested and other bacteria or protozoans. Therefore, caution must be used in the interpretation of the results, and the information obtained does not necessary reflect the behaviour of the pathogen in the natural aquatic environment (Austin \& Austin 1993).

The few data presently available about the survival of atypical strains are based only on laboratory results. For a proper evaluation of the possible spread of atypical strains from infected populations to uninfected ones more information is needed, especially on survival of different atypical strains in natural habitats. Additionally, more knowledge is needed on the effect of prolonged survival and starvation in water habitats on the maintenance of the virulence of the surviving cells.

\section{CONTROL}

The prophylactic and therapeutic methods available for the control of diseases caused by typical Aeromonas salmonicida have been reviewed by Austin \& Austin (1993). For diseases caused by atypical A. salmonicida less information about control is available. It appears that potentiated sulphonamide, chloramphenicol, neomycin, nitrofurantoin and oxytetracycline are generally effective against these pathogens (Bootsma et al. 1977, Csaba et al. 1980a, Gayer et al. 1980, Böhm et al. 1986, Groman et al. 1992, Pedersen et al. 1994, Jeney \& Jeney 1995).

The development of resistance to antibiotics among atypical strains has been observed by Hirvelä-Koski et al. (1994), who found resistance to sulfonamides. Strains isolated from turbot (Pedersen et al. 1994) were resistant to trimethoprim but sensitive to potentiated sulphonamide. Transferable drug resistance has been known to occur in typical Aeromonas salmonicida since 1959, when Aoki et al. (1971) demonstrated the presence of R-factors. Sandaa \& Enger (1996) demonstrated transfer of a naturally occurring plasmid (pRAS1), encoding multiple drug resistance, from atypical $A$. salmonicida to a variety of marine bacteria.

Little information is available about immunological protection of fish against infection with atypical Aeromonas salmonicida. Evenberg et al. (1986) and Pourreau et al. (1986) showed that carp infected with atypical $A$. salmonicida had a suppressed humoral immune response, while an experimental vaccine consisting of the same strain, demonstrated that ECP is important for protection (Evenberg et al. 1988). Daly et al. (1994) found that carp have memory formation in response to previous infection with atypical $A$. salmonicida and that the protection lasted for at least 5 mo. Vaccination against atypical 'furunculosis' (caused by atypical $A$. salmonicida) in reared Atlantic salmon in Newfoundland has not successfully eliminated carriers or alleviated disease in fresh or sea water (Groman et al. 1992). Hirst \& Ellis (1994) found that iron-regulated outer membrane proteins (IROMPs) of $A$. salmonicida represent protective antigens, which have an important role in the formulation of a successful vaccine against both typical and atypical strains of A. salmonicida.

Farmed salmonids have been vaccinated with good results against atypical 'furunculosis' in Iceland with an autogenous bacterin since 1992. Field studies indicated some cross-protection of the autogenous bacterin of Aeromonas salmonicida subsp. achromogenes against classical furunculosis (Guðmundsdóttir et al. 1996). However, in a recent study protection against classical furunculosis was not observed in fish vaccinated with an $A$. salmonicida subsp. achromogenes 
bacterin. The fish were kept in tanks under laboratory conditions. The authors suggested that a constant exposure to the bacterium under field conditions boosts and improves the immune response (Gudmundsdottir \& Gudmundsdóttir 1997). Gudmundsdóttir \& Magnadóttir (1997) have recently assessed the protective role of cell-associated and extracellular antigens of $A$. salmonicida subsp. achromogenes. The results indicate that a specific humoral immune response evoked in Atlantic salmon by a $20 \mathrm{kDa}$ extracellular metallocaseinase, AsaP1, is important in protection against experimental infection of A. salmonicida subsp. achromogenes. Jones et al. (1996) observed that vaccination against typical furunculosis protects against atypical A. salmonicida in salmonids and cyprinid fish. These authors suggested that antigens capable of eliciting protective immunity are conserved among biochemically diverse strains of $A$. salmonicida.

\section{CONCLUSIONS}

This review on atypical Aeromonas salmonicida demonstrates that, despite the large amount of information available about this important fish pathogen, substantial gaps remain in our knowledge not only about the non-specific factors influencing host specificity, virulence determinants, and survival of the pathogen in the environment but also about specific factors related to the atypical strains, including the relevance of these strains to farmed fish, their taxonomy, and the question of whether individual strains spread and, if so, how far.

Atypical Aeromonas salmonicida seems to infect a large number of fish species worldwide. The disease problems have shown themselves to be more conspicuous in farmed fish than in wild fish, where generally only small numbers of fish are diagnosed with ulcerations associated with atypical $A$. salmonicida. The infection studies carried out so far show that the virulence of atypical $A$. salmonicida varies according to the host species. These observations indicate, therefore, that there might be host species variation in susceptibility of different strains of atypical $A$. salmonicida. Some of the atypical strains isolated from wild fish adversely affect salmonids and therefore may represent a significant risk to farmed fish, both salmonids and non-salmonids. At present, there is a trend on introducing new non-salmonid fish species for farming purpose and the susceptibility of these fish species to atypical $A$. salmonicida has to be examined. Additionally, we need more information about the possible change of host specificity of atypical strains.

Studies on the role of the environment as a reservoir of atypical Aeromonas salmonicida would seem to be of particular importance. More work on the survival of the pathogen in water and sediment is needed, and it will be necessary to assess the capacity of the bacteria to survive in a non-culturable state and, in particular, to determine whether the virulence capability of the starving cells changes in aquatic environments. The bacteria have been isolated from clinically healthy fish, and it seems most likely that the fish have to be subjected to stressful conditions before the disease breaks out. At present, it is unknown whether the bacteria constitute a part of the normal flora of the fish, whether the pathogen is transmitted for long distances through the water, or whether transfer occurs from fish to fish, during spawning for example.

The biochemical identification of Aeromonas salmonicida to species level can be done, remembering that several of the atypical strains are fastidious and they need special growth media. In addition, strains of A. salmonicida with divergent characters are isolated both within the typical and atypical groups. Until the last decade the subspecies proposed by Schubert (1967) were easily distinguished by a limited number of biochemical characters. This classification was accepted by Bergey's Manual of Systematic Bacteriology (Popoff 1984). The proposal of McCarthy \& Roberts (1980) that $A$. salmonicida should be divided into different subspecies based on epizootiological criteria, with most of the atypical strains included into the subspecies nova, in hindsight seems to be too simple a solution. However, the present situation with 2 completely different systematic groups of subspecies is impractical and taxonomically inappropriate. There is an urgent need to clarify the taxonomic position of atypical strains, and identification of the different subspecies or groups of atypical $A$. salmonicida using molecular techniques will be a priority for future work.

With respect to fish health, the atypical strains are becoming more and more important, resulting in an increase in the demand for a valid definition of these pathogens and also for improved prevention and control procedures. Fish populations infected with atypical Aeromonas salmonicida have been transferred to geographical areas (countries) that are considered free of (classical) furunculosis (Whittington \& Cullis 1988), where spread of infection occurred because of unsuccessful attempts at treating the disease and absence of legislation. Should we accept the trading of fish infected with certain biotypes of atypical A. salmonicida, while infection with others is prohibited? Additionally, can a geographical area or country be considered free of $A$. salmonicida if atypical strains have been isolated from fish in that area. Certainly, more information, research and discussion are needed on these issues!

This review will hopefully provide a basis of information that can be useful in future studies on the species Aeromonas salmonicida. 
Acknowledgements. The authors thank their colleagues for the information and unpublished results reported in this paper.

\section{LITERATURE CITED}

Allen-Austin D, Austin B, Colwell RR (1984) Survival of Aeromonas salmonicida in river water FEMS (Fed Eur Microbiol Soc) Microbiol Lett 21:143-146

Altmann K, Marshall M, Nicholson SE, Hanna PJ, Gudkovs N (1992) Glucose repression of pıgment production in atypical isolates of Aeromonas salmonicida responsible for goldfish ulcer disease. Microbios 72:215-220

Anonymous (1992) International committee on systematic bacteriology subcommittee on the taxonomy of Vibrionaceae. Int J Syst Bacteriol 42:199-201

Aoki T, Egusa S, Kimura T, Watanabe T (1971) Detection of R factors in naturally occurring Aeromonas salmonicida strains. Appl Microbiol 22:716-717

Austin B (1993) Recovery of 'atypical' isolates of Aeromonas salmonicida, which grow at $37^{\circ} \mathrm{C}$, from ulcerated nonsalmonids in England. J Fish Dis 16:165-168

Austin B, Austin DA (1993) Aeromonadaceae representatives (Aeromonas salmonicida). In: Austin B, Austin DA (eds) Bacterial fish pathogens disease in farmed and wild fish, 2nd edn. Ellis Horwood Limited, Chichester, p 86-170

Austin DA. McIntosh D, Austin B (1989) Taxonomy of fish associated Aeromonas spp., with the description of Aeromonas salmonicida subsp. smithia subsp. nov. System Appl Microbiol 11:277-290

Bast L, Daly JG, DeGrandis SA, Stevenson RMW (1988) Evaluation of profiles of Aeromonas salmonicida as epidemiological markers of furunculosis infections in fish. J Fish Dis 11:133-145

Belland RJ, Trust TJ (1988) DNA:DNA reassociation analysis of Aeromonas salmonicida. J Gen Microbiol 134:307-315

Belland RJ, Trust TJ (1989) Aeromonas salmonicida plasmids: plasmid-directed synthesis of proteins in vitro and in Escherichia coli minicells. J Gen Microbiol 135:513-524

Benediktsdottir E. Helgason S (1990) The isolation of Aeromonas salmonicida subsp. achromogenes from the gills of salmonid fish. Bull Eur Assoc Fish Pathol 10:104-105

Boomker J, Henton MM, Naudé TW, Hunchzermeyer FW (1984) Furunculosis in rainbow trout (Salmo gairdneri) raısed in sea water. Onderstepoort J Vet Res 51:91-94

Bootsma R, Fijan N, Blommaert J (1977) Isolation and preliminary identification of the causative agent of carp erythrodermatitis, Vet Arh 47:291-302

Bucke D (1980) Experimental and naturally occurring furunculosis in various fish species: a comparative study In: Ahne W (ed) Fish diseases. Third COPRAQ-session Springer-Verlag, Berlin, p 82-86

Bucke D, Cawley GD, Craig JF, Pickering AD, Willough by LG (1979) Further studies of an epizootic of perch Perca fluviatilis L., of uncertain aetiology. J Fish Dis 2:297-311

Bulkley RV (1969) A furunculosis epizootic in Clear Lake yellow bass. Proc Annu Conf Bull Wildl Dis Assoc 5: $322-327$

Bullock GL, Cipriano RC, Snieszko SF (1983) Furunculosis and other diseases caused by Aeromonas salmonicida. US Fish and Wildlife Service, National Fish Health Research Laboratory, Kearneysville, Fish Disease Leaflet 66:1-29

Bullock GL, Conroy DA, Snieszko SF (1971) Bacterial diseases of fishes, Book 2A. In: Snieszko SF, Axelrod HR (eds) Diseases of fishes. TFH Publications, NJ, p 55-59

Böhm KH, Fuhrmann $H$, Schlotfeldt HJ, Körting W (1986) Aeromonas salmonicida from salmonids and cyprinids- serological and cultural identification. J Vet Med B 33 : $777-783$

Carson J, Handlinger J (1988) Virulence of the aetiological agent of goldfish ulcer disease in Atlantic salmon, Salmo salar L. J Fish Dis 11:471-479

Chapman PF, Cipriano RC, Teska JD (1991) Isolation and phenotypic characterization of an oxidase-negatıve Aeromonas salmonicida causing furunculosis in coho salmon (Oncorhynchus kisutch). J Wild! Dis 27:61-67

Chart H, Shaw DH, Ishıguro EE, Trust TJ (1984) Structural and immunochemical homogeneity of Aeromonas salmonicida lipopolysaccharide. J Bacteriol 158:16-22

Chart H. Trust TJ (1983) Acquisition of iron by Aeromonas salmonicida. J Bacteriol 156:758-764

Colwell RR, MacDonell MT, De Ley J (1986) Proposal to recognize the family Aeromonadaceae fam. nov. Int $J$ Syst Bacteriol 36:473-477

Cornick JW, Morrison CM, Zwicker B, Shum G (1984) Atypical Aeromonas salmonicida infection in Atlantic cod, Gadus morhua L. J Fish Dis 7:495-499

Csaba G, Körmendy B, Békési L (1980a) Observations on the causative agent of carp erythrodermatitis in Hungary. Bull Off Int Epizoot 92:1047-1053

Csaba G, Körmendy B, Bekesi L (1980b) Examination of the $C E$ agent. In: Ahne $W$ (ed) Fish diseases. Third COPRAQsession. Springer-Verlag, Berlin, p 126

Dalsgaard I (1994a) Ribotyping and plasmid profiling of atypical Aeromonas salmonicida for epizootıological studies of skin ulcer disease in flounder (Platichthys flesus). In: Bylund G, Lönnstrom LG (eds) Diseases and parasites of flounder (Platichthys flesus) in the Baltic Sea. Balt Mar Biol 15:35-38

Dalsgaard I (1994b) Ulcer disease in fish. Occurrence, aetiology and significance. Fisk Hav, Skr Danm Fiskeri Havunders 45:57-64

Dalsgaard I, Gudmundsdóttir BK, Helgason S, Høie S, Thoresen OF, Wichardt UP, Wiklund T (1998) Identification of atypical Aeromonas salmonicida: inter-laboratory evaluation and harmonization of methods. J Appl Microbiol (in press)

Dalsgaard I, Mortensen Á (1988) Bacteriological problems in commercial farming in the Faroe Islands. Abstract, 3rd Internat Collog Pathol Marine Aquacul, 2-6 Oct 88, Gloucester Point, VA, p 13

Dalsgaard I, Paulsen H (1986) Atypical Aeromonas salmonicida isolated from diseased sand-eels. Ammodytes lancea (Cuvier) and Hyperoplus lanceolatus (Lesauvege). J Fish Dis 9:361-364

Daly JG, Wiegertjes GF, van Muiswinkel WB (1994) Protection against carp erythrodermatitis following bath or subcutaneous exposure to sublethal numbers of virulent Aeromonas salmonicida subsp. nova. J Fish Dis 17:67-75

Donlon J, McGettigan S, O'Brien P, O Carra P (1983) Reappraisal of the nature of the pigment produced by Aeromonas salmonicida. FEMS (Fed Eur Microbiol Soc) Microbiol Lett 19:285-290

Effendi I, Austin B (1994) Survival of the fish pathogen Aeromonas salmonicida in the marine environment. J Fish Dis $17: 375-385$

Elliott DG, Shotts EB Jr (1980a) Aetiology of an ulcerative disease in goldfish Carassius auratus (L.): microbiological examination of diseased fish from seven locations. J Fish Dis 3:133-143

Elliott DG, Shotts EB Jr (1980b) Aetiology of an ulcerative disease in goldfish, Carassius auratus (L.): experimental induction of the disease. J Fish Dis 3:145-151

Ellis AE, Burrows AS, Stapleton KJ (1988) Lack of relationship 
between virulence of Aeromonas salmonicida and the putative virulence factors: A-layer, extracellular proteases and extracellular haemolysins. J Fish Dis 11:309-323

Estcve C, Gutiérrez MC, Ventosa A (1995) DNA relatedness among Aeromonas allosaccharophila strains and DNA hybridization groups of the genus Aeromonas. Int J Syst Bacteriol 45:390-391

Evelyn TPT (1971) An aberrant strain of the bacterial fish pathogen Aeromonas salmonicida isolated from a marine host, the sablefish (Anoplopoma fimbria), and from two species of cultured Pacific salmon. J Fish Res Bd Can 28 1629-1634

Evenberg $D$, van Boxtel $R$, Lugtenberg $B$, Schurer F, Blommaert J, Bootsma R (1982) Cell surface of the fish pathogenic bacterium Aeromonas salmonicida I. Relationship between autoagglutination and the presence of a major cell envelope protein. Biochim Biophys Acta 684:241-248

Evenberg D, de Graaff $P$, Fleuren W, van Muiswinkel WB (1986) Blond changes in carp (Cyprinus carpio) induced by ulcerative Aeromonas salmonicida infections. Vet Immunol. Immunopathol 12:321-330

Evenberg D, de Graaff $\mathrm{P}$, Lugtenberg B, van Muiswinkel WB (1988) Vaccine-induced protective immunity against Aeromonas salmonicida tested in experimental carp erythrodermatitis. J Fish Dis 11:337-350

Evenberg D, Lugtenberg B (1.982) Cell surface of the fish pathogenic bacterium Aeromonas salmonicida II. Purification and characterization of a major cell envelope protein related to autoagglutination, adhesion and virulence. Biochim Biophys Acta 684:249-254

Ferguson Y, Glover LA, McGillivray DM, Prosser JI (1995) Survival and activity of lux-marked Aeromonas salmonicida in seawater. Appl Environ Microbiol 61:3494-3498

Fijan NN (1972) Infectious dropsy in carp-a disease complex. Symp Zool Soc Lond 30:39-51

Frerichs GN, Millar SD, McManus C (1992) Atypical Aeromonas salmonicida isolated from healthy wrasse (CtenoJabrus rupestris). Bull Eur Assoc Fish Pathol 12:48-49

Gayer EK, Bekesi L, Csaba G (1980) Some aspects of the histopathology of carp erythrodermatitis (CE). In: Ahne W (ed) Fish diseases. Third COPRAQ-session. SpringerVerlag, Berlin, p 127-136

Gravningen K, Dydland M (1991) Diseases in turbot (Scophthalmus maximus L.). Norsk Veterinartidsskrift 103: 923-926

Gravningen K, Kvenseth PG, Hovlid RO (1996) Virulence of Vibrio anguillarum serotypes $\mathrm{O} 1$ and $\mathrm{O} 2$, Aeromonas salmonicida subsp. salmonicida and atypical Aeromonas salmonicida to goldsinny wrasse. In: Sayer MDJ, Treasurer JW, Costello MJ (eds) Wrasse: biology and use in aquaculture. Fishing News Books, Farnham, p 247-250

Griffin PJ, Snieszko SF. Friddle SB (1953a) A more comprehensive description of Bacterium salmonicida. Trans Am Fish Soc 82:129-138

Griffin PJ, Snieszko SF, Friddle SB (1953b) Pigment formation by Bacterium salmonicida. J Bact 65:652-659

Groman D, Tweedie D, Shaw D (1992) Experiences with atypical furunculosis in Newfoundland: an overview. Bull Aquacul Assoc Can 1.36-39

Gudmundsdóttir BK (1996) Comparison of extracellular proteases produced by Aeromonas salmonicida strains, isolated from various fish species. J Appl Bacteriol 80: $105-113$

Gudmundsdóttir BK, Gudmundsdóttir S (1997) Evaluation of cross protection by vaccines against atypical and typical furunculosis in Atlantic salmon, Salmo salar L. J Fish Dis $20: 343-350$
Guòmundsdóttir BK, Guðrmundsdóttır S, Maqnadóttir B, Helgason S (1996) Research in bacterial diseases of salmonid fish. Læknabladio 82:72-77

Gudmundsdottir BK, Hastings TS, Ellis AE (1990) Isolation of a new toxic protease from a strain of Aeromonas salmonicida subspecies achromogenes. Dis Aquat Org 9:199-208

Gudmundsdóttir BK, Magnadóttir B (1997) Protection of Atlantic salmon (Sulmo salar L.) against an experimental infection of Aeromonas salmonicida ssp. achromogenes. Fish Shellfish Immunol 7:55-69

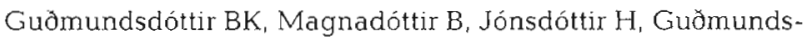
dóttir S, Helgason S, Jónsson G (1995) Atypical furunculosis in Icelandic aquaculture. Abstracts book, European Association of Fish Pathologists, Seventh International Conference 'Diseases of fish and shellfish', Palma de Mallorca, 10-15 September 1995, p 20

Hastings TS, Ellis AE (1985) Differences in the production of haemolytic and proteolytic activities by various isolates of Aeromonas salmonicida. In: Ellis AE (ed) Fish and shellfish pathology. Academic Press, London, p 69-77

Hellberg H, Moksness E, Høie S (1996) Infection with atypical Aeromonas salmonicida in farmed common wolffish, Anarhichas lupus L. J Fish Dis 19:329-332

Hirst ID, Ellis AE (1994) Iron-regulated outer membrane proteins of Aeromonas salmonicida are important protective antigens in Atlantic salmon against furunculosis. Fish Shellfish Immunol 4:29-45

Hirst ID, Ellis AE (1996) Utilization of transferrin and salmon serum as sources of iron by typical and atypical strains of Aeromonas salmonicida. Microbiology 142:1543-1550

Hirst ID, Hastings TS, Ellis AE (1991) Siderophore production by Aeromonas salmonicida. J Gen Microbiol 137: $1185-1192$

Hirst ID, Hastings TS, Ellis AE (1994) Utilization of haem compounds by Aeromonas salmonicida. J Fish Dis 17:365-373

Hirvelä-Koski V, Koski P, Niiranen H (1994) Biochemical properties and drug resistance of Aeromonas salmonicida in Finland. Dis Aquat Org 20:191-196

Holt JG, Krieg NR, Sneath PHA, Staley JT, Williams ST (1994) Bergey's manual of determinative bacteriology, 9th edn. Williams \& Wilkins, Baltimore, p 175-289

Hubbert RM, Williams WP (1980) Ulcer disease of roach, Rutilus rutilus (L.). Bamidgeh 32:46-52

Humphrey JD, Ashburner LD (1993) Spread of the bacterial fish pathogen Aeromonas salmonicida after importation of infected goldfish, Carassius auratus, into Australia. Australian. Vet J 70:453-454

Husevåg B (1994) Survival of Aeromonas salmonicida and Vibrio salmonicida in marine fish farm environments. $\mathrm{PhD}$ thesis, University of Bergen, Norway

Håstein T, Saltveit SJ, Roberts RJ (1978) Mass mortality among minnows Phoxinus phoxinus (L.) in Lake Tveitevatn, Norway, due to an aberrant strain of Aeromonas salmonicida. J Fish Dis 1:241-249

Iida T, Nakakoshi K. Wakabayashi $H$ (1984) Isolation of atypical Aeromonas salmonicida from diseased eel, Anguilla japonica. Fish Pathol 19:109-112

Ishiguro EE, Ainsworth T, Kay WW, Trust TJ (1986) Heme requirement for growth of fastidious atypical strains of Aeromonas salmonicida. Appl Environ Microbiol 51. $668-670$

Jeney Z, Jeney G (1995) Recent achievements in studies on diseases of common carp (Cyprinus carpio L.). Aquaculture 129:397-420

Jones SRM, Osinchuk RD, Mackinnon AM, Markham RJF (1996) Vaccination against typical furunculosis protects against atypical Aeromonas salmonicida in salmonid and 
cyprinid fish. Abstract, International Symposium on Fish Vaccinology, 5-7 June 1996, Oslo, Norway, p 79

Kay WW, Buckley JT, Ishiguro EE, Phipps BM, Monette JPL, Trust TJ (1981) Purification and disposition of a surface protein associated with virulence of Aeromonas salmonicida. J Bacteriol 147:1077-1084

Kay WW, Phipps BM. Ishiguro EE, Olafson RW, Trust TJ (1984) Surface layer virulence A-proteins from Aeromonas salmonicida strains. Can J Biochem Cell Biol 62: $1064-1071$

Kimura T (1969a) A new subspecies of Aeromonas salmonicida as an etiological agent of furunculosis on 'sakuramasu' (Oncorhynchus masou) and pink salmon (O. gorbuscha) rearing for maturity. Part 1 . On the morphological and physiological properties. Fish Pathol 3:34-44

Kimura $T$ (1969b) A new subspecies of Aeromonas salmonicida as an etiological agent of furunculosis on 'Sakuramasu' (Oncorhynchus masou) and pink salmon (O. gorbuscha) rearing for maturity. Part 2. On the serological properties. Fish Pathol 3:45-52

Kitao T, Yoshida T, Aoki T, Fukudome M (1984) Atypical Aeromonas salmonicida, the causative agent of an uicer disease of eel occurred in Kagoshima prefecture. Fish Pathol 19:113-117

Kitao T, Yoshida T, Aoki T, Fukudome M (1985) Characterization of an atypical Aeromonas salmonicida strain causing epizootic ulcer disease in cultured eel. Fish Pathol 20 : $107-114$

Kluyver A.J, van Niel CB (1936) Prospects for a natural system of classification of bacteria. Zentralbl Bakteriol Parasitenkd Infektionskr 2. Abt 94:369-403

Larsen JL, Pedersen K (1996) Atypical Aeromonas salmonicida isolated from diseased turbot (Scophtalmus maximus L.). Acta Vet Scand 37:139-146

LeTendre GC, Schneider CP, Ehlınger NF (1972) Net damage and subsequent mortality from furunculosis in smallmouth bass. NY Fish Game J 19:73-82

Ljungberg O, Johansson N (1977) Epizootiological studies on atypical Aeromonas salmonicida infections of salmonids in Swedish fish farms, 1967-1977. Bull Off Int Epizoot 87 $475-478$

MacInnes JI, Trust TJ, Crosa JH (1979) Deoxyribonucleic acid relationships among members of the genus Aeromonas. Can J Microbiol 25:579-586

Magarinos B, Romalde $\mathrm{JL}$, Bandín I, Fouz B, Toranzo AE (1992) Phenotypic, antigenic, and molecular characterization of Pasteurella piscicida strains isolated from fish. Appl Environ Microbiol 58:3316-3322

Martinez-Murcia AJ, Benlloch S, Collins MD (1992) Phylogenetic interrelationships of members of the genera Aeromonas and Plesiomonas as determined by $16 \mathrm{~S}$ ribosomal DNA sequencing: lack of congruence with results of DNADNA hybridizations. Int J Syst Bacteriol 42:412-421

Mawdesley-Thomas LE (1969) Furunculosis in the goldfish Carassius auratus (L.). J Fish Biol 1:19-23

McCarthy DH (1975) Fish furunculosis caused by Aeromonas salmonicida var. achromogenes. J Wildl Dis 11:489-493

McCarthy DH (1977) The identification and significance of atypical strains of Aeromonas salmonicida. Bull Off lnt Epizoot 87:459-463

McCarthy DH (1978) A study of the taxonomic status of some bactenia currently assigned to the genus Aeromonas. PhD thesis, Council for National Academic Awards, Weymouth, UK

McCarthy DH, Roberts RJ (1980) Furunculosis of fish - the present state of our knowledge. In: Droop MR, Jannasch HW (eds) Advances in aquatic microbiology. Academic
Press, London, p 293-341

McCormick WA, Stevenson RMW, Maclnnes Jl (1990) Restriction endonuclease fingerprinting analysis of Canadian isolates of Aeromonas salmonicida. Can J Microbiol $36: 24-32$

Mcintosh D, Austın B (1991) Atypical characteristics of the salmonid pathogen Aeromonas salmonicida. J Gen Microbiol 137:1341-1343

Michel C (1981) A bacterial disease of perch (Perca fluviatilis L.) in an alpine lake: isolation and preliminary study of the causative organism. J Wildl Dis 17:505-510

Michel C. Dubois-Darnaudpeys A (1980) Persistence of the virulence of Aeromonas salmonicida strains kept in river sediments. Ann Rech Vet 11:375-380

von Mirle $\mathrm{C}$, Bocklisch $\mathrm{H}$, Engelhardt A, Freudenberg $\mathrm{K}$, Hiltner R (1986) Studies into aetiology of erythrodermatitis of carp. Mh Vet-Med 41:559-562

Morgan JAW, Cranwell PA, Pickup RW (1991) Survival of Aeromonas salmonicida in lake water. Appl Environ Microbiol 57:1777-1782

Morrison CM, Cornick JW, Shum G, Zwicker B (1984) Histopathology of atypical Aeromonas salmonicida infection in Atlantic cod, Gadus morhua L. J Fish Dis 7:477-494

Munkittrick KR, Leatherland JF (1984) Abnormal pituitarygonad function in two feral populations of goldfish, Carassius auratus (L.), suffering epizootics of an ulcerative disease. J Fish Dis 7:433-447

Möller $\mathrm{H}$ (1990) Association between diseases of flounder (Platichthy's flesus) and environmental conditions in the Elbe estuary, FRG. J Cons Int Explor Mer 46:187-199

Nakatsugawa T (1994) Atypical Aeromonas salmonicida isolated from cultured shotted halibut. Fish Pathol 29:193-198

Noga EJ, Berkhoff HA (1990) Pathological and microbiological features of Aeromonas salmonicida infection in the American eel (Anquilla rostrata). Fish Pathol 25:127-132

Nounou P, Martoja R, Orcel L (1981) Ulcerations of marine fishes and mammals caught in the French coastal waters Publ French Nat Centre Exploit Oceans 43:1-99

Ohtsuka H, Nakai T, Muroga K, Jo Y (1984) Atypical Aeromonas salmonicida isolated from diseased eels. Fish Pathol 19:101-107

Ojala $O(1966)$ lsolation of an anaerogenic bacterium resembling Aeromonas salmonicida in spawning lake trouts. Bull Off Int Epizoot 65:793-804

Olivier G (1990) Virulence of Aeromonas salmonicida: lack of relationship with phenotypic characteristics. J Aquat Anim Health 2:119-127

Olivier G (1992) Furunculosis in the Atlantic Provinces: an overview. Bull Aquacul Assoc Can 1:4-10

Olsen AB, Lunder T, Reitan LJ (1989) Infection with a particular strain of atypical Aeromonas salmonicida in Norway. Abstracts book, European Association of Fish Pathologists, Fourth international conference 'Diseases of fish and shellfish', Santiago de Compostela, Spain, 24-28 September 1989, p 199

Paterson WD, Douey D, Desautels D (1980a) Relationships between selected strains of typical and atypical Aeromonas salmonicida, Aeromonas hydrophila, and Haemophilus piscium. Can J Microbiol 26:588-598

Paterson WD, Douey D, Desautels D (1980b) Isolation and identification of an atypical Aeromonas salmonicida strain causing epizootic losses among Atlantic salmon (Salmo salar) reared in a Nova Scotian hatchery. Can J Fish Aquat Sci 37:2236-2241

Pedersen K, Dalsgaard I, Larsen JL (1996) Characterization of atypical Aeromonas salmonicida isolates by ribotyping and plasmid profiling. J Appl Bacteriol 80:37-44 
Pedersen K, Kofod H, Dalsgaard I, Larsen JL (1994) Isolation of oxidase-negative Aeromonas salmonicida from diseased turbot Scophthalmus maximus. Dis Aquat Org 18:149-154

Pol JMA, Bootsma R, vd Berg-Blommaert JM (1980) Pathogenesis of carp erythrodermatitis (CE): role of bacterial endo- and exotoxin. In: Ahne $W$ (ed) Fish diseases. Third COPRAQ-session. Springer-Verlag, Berlin, p 120-125

Popoff M (1984) Genus III. Aeromonas Kluyver and Van Niel 1936, 398 AL In: Krieg NR, Holt JG (eds) Bergey's manual of systematic bacteriology, Vol 1. Williams \& Wilkins, Baltimore, p 545-548

Pourreau CN, Evenberg $D$, de Raadt WM, van Mechelen JAN, van Muiswinkel WB (1986) Does Aeromonas salmonicida affect the immune system of carp. Cyprinus carpio L.? Vet Immunol Immunopathol 12:331-338

Pylkkö P (1993) The effect of feeding and rearing density on the susceptibility to ASA disease of grayling (Thymallus thymallus L.) and Arctic char (Salvelinus alpinus L.). Kalatutkimuksia - Fiskundersökningar 74:1-19

Rintamäki P, Valtonen ET (1991) Aeromonas salmonicida in Finland: pathological problems associated with atypical and typical strains. J Fish Dis 14:323-331

Rose AS, Ellis AE, Munro ALS (1990) The survival of Aeromonas salmonicida subsp. salmonicida in sea water. J Fish Dis 13:205-214

Sandaa RA, Enger $\varnothing$ (1996) High frequency transfer of a broad host range plasmid present in an atypical strain of the fish pathogen Aeromonas salmonicida. Dis Aquat Org $24: 71-75$

Schubert RHW (1967) The taxonomy and nomenclature of the genus Aeromonas Kluyver and Van Nicl 1936. Part II. Suggestions on the taxonomy and the nomenclature of the anaerogenic aeromonads. Int J Syst Bacteriol 17: 273-279

Schubert RHW (1969) On the taxonomy of Aeromonas salmonicida subsp. achromogenes (Smith 1963) Schubert 1967 and Aeromonas salmonicida subsp. masoucida Kimura 1969. Zentralbl Bakteriol Parasitenkd Infektionskr Hyg Abt I Orig 211:413-41.7

Shotts EB Jr, Talkington FD, Elliott DG, McCarthy DH (1980) Aetiology of an ulcerative disease in goldfish. Carassius auratus (L.): characterization of the causative agent. J Fish Dis 3:181-186

Sioutas S, Hoffmann RW, Pfeil-Putzien C, Fischer-Scherl I (1991) Carp erythrodermatitis (CE) due to an Aeromonas hydrophila infection. J Vet Med B 38:186-194

Skerman VBD. McGowan V. Sneath PHA (1980) Approved lists of bacterial names. Int J Syst Bacteriol 30:225-420

Smith IW (1963) The classification of 'Bacterium salmonicida'. J Gen Microbiol 33:263-274

Snieszko SF, Griffin PJ, Friddle SB (1950) A new bacterium (Hemophilus piscium $\mathrm{n}$. sp.) from ulcer disease of trout. J Bacteriol 59:699-710

Sövényi JF (1986) Applicability of coagglutination test for detecting Aeromonas salmonscida antigens from extracts of bacterial cultures and experimentally infected. tissues of the common carp (Cyprinus carpio L.). Acta Vet Hung 34:151-158

Sövényi JF, Bercsényi M, Bakos J (1988) Comparative examjnation of susceptibility of two genotypes of carp (Cyprinus carpio L.) to infection with Aeromonas salmonicida. Aquaculture 70:301-308

Sövényi JF, Elliott DG, Csaba G, Oláh J, Majnarich JJ (1984) Cultural, biochemical and serological characteristics of bacterial isolates from carp erythrodermatitis in Hungary. Rev Sci Tech Off Int Epizoot 3:597-609

Sövényi J, Ruttkay A (1986) Experimental examination of correlation between nutrition status and susceptibility of carp (Cyprinus carpio L.) to carp erythrodermatitis. Aquacultura Hungarica 5:119-126

Takahashi K, Kawana T, Nakamura T (1975a) Studies on ulcer disease of goldfish-I. Site of occurrence of ulcer. Fish Pathol 9:174-178

Takahashi K, Kawana T, Nakamura T (1975b) Studies on ulcer disease of goldfish-III. Infection experiments. Fish Pathol 9:187-192

Takahashi K, Kawana T, Nakamura I (1975c) Studies on ulcer disease of goldfish - VI. Bacteria isolated from lesions of diseased fish. Fish Pathol 10:22-30

Traxler GS, Bell GR (1988) Pathogens associated with impounded Pacific herring Clupea harengus pallasi, with emphasis on viral erythrocytic necrosis (VEN) and atypical Aeromonas salmonicida. Dis Aquat Org 5:93-100

Trust TJ, Howard PS, Chamberlain JB, Ishiguro EE, Buckley JT (1980a) Additional surface protein in autoaggregating strains of atypical Aeromonas salmonicida. FEMS (Fed Eur Micrabioi Soc) Microbiol Lett 9:35-38

Trust TJ, Ishiguro EE, Atkinson HM (1980b) Relationship between Haemophilus piscium and Aeromonas salmonicida revealed by Aeromonas hydrophila bacteriophage. FEMS (Fed Eur Microbiol Soc) Microbiol Lett 9:199-201

Trust TJ, Khouri AG, Austen RA, Ashburner LD (1980c) First isolation in Australia of atypical Aeromonas salmonicida FEMS (Fed Eur Microbiol Soc) Microbiol Lett 9:39-42

Ullrich S (1992) Bakterielle Fischkrankheiten in Untereider und Unterelbe und ihre Beeinflussung durch Umweltfaktoren. Berichte aus dem Institut für Meereskunde an der Christian-Albrechts-Universität, Kiel, Nr 223

Vethaak AD (1992) Diseases of flounder (Platichthys flesus L.) in the Dutch Wadden Sea, and their relation to stress factors. Neth J Sea Res 29:257-272

Whittington RJ, Cullis B (1988) The susceptibility of salmonid fish to an atypical strain of Aeromonas salmonicida that infects goldfish, Carassius auratus (L.), in Australia. J Fish Dis 11:461-470

Whittington RJ, Djordjevic SP, Carson J, Callinan RB (1995) Restriction endonuclease analysis of atypical Aeromonas salmonicida isolates from goldfish Carassius auratus, silver perch Bidyanus bidyanus, and greenback flounder Rhombosolea tapirina in Australia. Dis Aquat Org 22 1.85-191

Whittington RJ, Gudkovs N, Carrigan MJ, Ashburner LD Thurstan SJ (1.987) Clinical, microbiological and epidemiological findings in recent outbreaks of goldfish ulcer dis ease due to atypical Aeromonas salmonicida in southeastern Australia. J Fish Dis 10:353-362

Wichardt UP (1983a) Atypical Aeromonas salmonicidainfection in sea-trout (Salmo trutta, L.) I. Epizootological studies, clinical signs and bacteriology. Laxforskningsinst Meddelande 6:1-10

Wichardt UP (1983b) Atypical Aeromonas salmonicidainfection in sea-trout (Salmo trutta L.) II. Influence of water-temperature and stocking density on the infection rate. Laxforskningsinst Meddelande 7:1-14

Wichardt UP, Johansson N, Ljungberg $O$ (1989) Occurrence and distribution of Aeromonas salmonicida infections on Swedish fish farms, 1951-1987. J Aquat Animal Health $1: 187-196$

Wiegertjes GF, Daly JG, van Muiswinkel WB (1993) Disease resistance of carp. Cyprinus carpio L.: identification of individual genetic differences by bath challenge with atypical Aeromonas salmonicida. J Fish Dis 16:569-576

Wiklund T (1990) Atypical Aeromonas salmonicida isolated from ulcers of pike, Esox lucius L. J Fish Dis 13:541-544 Wiklund T (1994.a) Skin ulcer disease of flounder (Platichthys 
flesus): disease patterns and characterization of an etiological agent, PhD thesis, Åbo Akademi University, Abo, Finland

Wiklund T (1994b) Skin ulcer disease of flounder (Platichthys flesus): a review. In: Bylund G, Lönnström L (eds) Diseases and parasites of flounder (Platichthys flesus) in the Baltic Sea. Balt Mar Biol 15:17-26

Wiklund T (1995a) Survival of 'atypical' Aeromonas salmonicida in water and sediment microcosms of different salinities and temperatures. Dis Aquat Org 21:137-143

Wiklund T (1995b) Virulence of 'atypical' Aeromonas salmonicida isolated from ulcerated flounder Platichthys flesus. Dis Aquat Org 21:145-150

Wiklund T, Bylund G (1991) A cytochrome oxidase negative bacterium (presumptively an atypical Aeromonas salmonicida) isolated from ulcerated flounders (Platichthys flesus (L.)) in the northern Baltic Sea. Bull Eur Assoc Fish Pathol 11:74-76

Wiklund T, Bylund G (1993) Skin ulcer disease of flounder Platichthys flesus in the northern Baltic Sea. Dis Aquat Org 17:165-174

Wiklund T, Dalsgaard I (1995) Atypical Aeromonas salmoni-

Editorial responsibility: David Bruno,

Aberdeen, Scotland, UK cida associated with ulcerated flatfish species in the Baltic Sea and the North Sea. J Aquat Anim Health 7:218-224

Wiklund T, Dalsgaard I, Eerola E, Olivier G (1994) Characteristics of 'atypical', cytochrome oxidase-negative Aeromonas salmonicida isolated from ulcerated flounders (Platichthys flesus (L.)). J Appl Bacteriol 76:511-520

Wiklund T, Lönnström L, Niiranen H (1993) Aeromonas salmonicida ssp. salmonicida lacking pigment production, isolated from farmed salmonids in Finland. Dis Aquat Org 15:219-223

Wiklund T, Sazonov A, L'Iniova GP, Pugaewa VP, Zoobaha SV, Bylund G (1992) Characteristics of Aeromonas salmonicida subsp. salmonicida isolated from wild Pacific salmonids in Kamchatka, Russia. Bull Eur Assoc Fish Pathol 12:76-79

Wilson BW, Holliman A (1994) Atypical Aeromonas salmonicida isolated from ulcerated chub Leuciscus cephalis. Vet $\operatorname{Rec} 135: 185-186$

Yoshimizu M, Direkbusarakom S, Ezura Y, Kimura T (1993) Monoclonal antibodies against Aeromonas salmonicida for serological diagnosis of furunculosis. Nippon Suisan Gakkaishi 59:333-338

Submitted: April 4, 1997; Accepted: November 14, 1997

Proofs received from author(s): February 10, 1998 